$\begin{array}{ll} & \text { Etnográfica } \\ \text { etnográfica } & \text { Revista do Centro em Rede de Investigação em }\end{array}$

Antropologia

vol. 19 (1) | 2015

Vol. $19(1)$

\title{
Saberes e práticas de cura nas igrejas neotradicionais em Luanda: carismas, participação e trajetórias das mulheres
}

Knowledge and healing practices in the neo-traditional churches in Luanda:

charisma, participation and women biographies

\section{Fátima Viegas e Jorge Varanda}

\section{(2) OpenEdition}

\section{Journals}

\section{Edição electrónica}

URL: https://journals.openedition.org/etnografica/3957

DOI: 10.4000/etnografica.3957

ISSN: 2182-2891

\section{Editora}

Centro em Rede de Investigação em Antropologia

\section{Edição impressa}

Data de publição: 1 fevereiro 2015

Paginação: 189-224

ISSN: 0873-6561

\section{Refêrencia eletrónica}

Fátima Viegas e Jorge Varanda, «Saberes e práticas de cura nas igrejas neotradicionais em Luanda: carismas, participação e trajetórias das mulheres», Etnográfica [Online], vol. 19 (1) | 2015, posto online no dia 06 março 2015, consultado o 09 fevereiro 2022. URL: http://journals.openedition.org/ etnografica/3957 ; DOI: https://doi.org/10.4000/etnografica.3957

\section{(c) (7) \&}

Etnográfica is licensed under a Creative Commons Attribution-NonCommercial 4.0 International License. 


\section{Saberes e práticas de cura nas igrejas neotradicionais em Luanda: carismas, participação e trajetórias das mulheres}

\section{Fátima Viegas e Jorge Varanda}

O presente artigo analisa as visões da doença e as trajetórias de vida de mulheres carismáticas observadas em algumas igrejas neotradicionais localizadas no espaço urbano e periurbano de Luanda. As profetisas têm um papel central no espaço sociocultural ecuménico da capital, realçando como a (re)interpretação das suas biografias no contexto religioso permite criar dinâmicas sociais inovadoras que são engendradas nos campos da saúde e da religião. Estas igrejas ergueram templos e casas de oração e de cura, convertem e arrastam multidões, refizeram códigos de ética e de conduta religiosa e moral, e têm um papel central na renovação de certos rituais, com particular acuidade para a cura religiosa.

PALAVRAS-CHAVE: igrejas neotradicionais, carisma, profetisas, doença e cura, itinerário terapêutico.

Knowledge and healing practices in the neo-traditional churches in Luanda: charisma, participation and women biographies - This article focuses on the biographies of charismatic women belonging to the neo-traditional churches located in urban and peri-urban areas of Luanda and on local views of the disease and its cure. These female prophets play a central role in the ecumenical social-cultural space of the capital of Angola, and the (re)interpretation of their biographies in a religious context highlights the ways that they create innovative social dynamics embedded in the fields of health and religion. These churches have built temples and houses of prayer and healing, that draw large crowds of believers; have re-shaped codes of ethical, religious and moral conduct; and have played a central role in the renewal of certain rituals, particularly those related to religious healing.

KEYWORDS: neo-traditional churches, charisma, female prophets, disease and cure, therapeutic itinerary.

VIEGAS, Fátima (fatimaviegas49@hotmail.com) - Universidade Agostinho Neto, Angola; Centro de Estudos e Intervenção Social (CEIS), Angola.

VARANDA, Jorge (jorge.varanda@gmail.com) - Centro em Rede de Investigação em Antropologia (CRIA), ISCTE - Instituto Universitário de Lisboa (ISCTE-IUL), Portugal; Centro de Malária e Doenças Tropicais (CMDT-LA), Instituto de Higiene e Medicina Tropical, Portugal. 


\section{INTRODUÇÃO}

A efervescência no campo religioso verificada na sociedade angolana, e luandense em particular, principalmente depois da abertura legislativa da década de 90 do século XX, despertou a curiosidade científica para a realização de um estudo sobre esta temática e o impacto do fenómeno na capital angolana. Este artigo é corolário de uma pesquisa mais abrangente e continuada sobre o fenómeno religioso, com especial destaque para os movimentos religiosos carismáticos, pentecostais, proféticos e neotradicionais que surgiram em Angola nas três últimas décadas (Viegas 2005, 2007, 2008; Sarró, Blanes e Viegas 2008). ${ }^{1}$

O trabalho de campo foi realizado de janeiro a março de 2002 e de setembro a dezembro de 2003, sendo o terreno posteriormente revisitado no início de $2010 .^{2}$ A área de trabalho centrou-se no espaço urbano e periurbano da província de Luanda, ou seja, englobou uma vasta área semicircular continuamente urbanizada que se estende até Viana. A Igreja Teosófica Espírita localiza-se no município da Ingombota, Bairro Maculusso; a Igreja dos Primogénitos Evangélica Universal em Angola situa-se no município do Sambizanga, bairro Petrangol; o Centro de Devoção Rainha Santa Isabel está presente no município da Maianga, no bairro Morro Bento; a Comunidade do Espírito Santo da Igreja da Geração Prometida situa-se no município Cazenga, no bairro Cazenga, e em Viana, no bairro da Caop; em Viana, há ainda a Igreja Fé da Salvação do Espírito Santo (Ifesa).

É neste espaço que se encontram as igrejas neotradicionais em destaque neste texto, três por serem lideradas por mulheres - a Igreja Teosófica Espírita pela profetisa Suzete Francisco, o Centro de Devoção Rainha Santa Isabel pela profetisa Maria da Conceição Mendes, a Ifesa pela profetisa Teresa -, e as outras porque, embora sejam lideradas por pastores, têm na sua maioria mulheres como responsáveis pela cura espiritual. ${ }^{3}$ Nesta área, situado em

I Este artigo foi o corolário de discussões de ideias efetuadas in situ graças ao financiamento pela Fundação para a Ciência e a Tecnologia (FCT) do projeto PTDC/AFR/100646/2008.

2 Lista de igrejas neotradicionais surgidas no espaço urbano e periurbano de Luanda, na década de 1990, e onde foi realizado trabalho de terreno mais amplo entre várias igrejas: 1) Igreja Profética Vencedora no Mundo; 2) Igreja Apostólica Africana em Angola; 3) Igreja Fraternidade Evangélica de Pentecostes na África, em Angola: Bom Deus; 4) Missão Evangélica do Espírito Santo em Angola; 5) Igreja do Espírito Santo e Profética de Angola; 6) Igreja dos Doze Apóstolos; 7) Igreja do Catecismo de Jesus do Espírito Santo; 8) Igreja de Jesus; 9) Igreja Teosófica Espírita; 10) Assembleia Espiritual de Cristo em Angola; 11) Igreja dos Primogénitos Evangélica Universal em Angola; 12) Igreja Jesus Cristo do Espírito da Verdade - Bima; 13) Igreja do Messias em Espírito Santo; 14) Centro de Devoção Rainha Santa Isabel; 15) Igreja Sagrada Esperança Universal Fonte Espiritual em Angola; 16) Igreja de Deus Vivo; 17) Igreja da Salvação Evangélica do Espírito Santo; 18) Comunidade do Espírito Santo da Igreja da Geração Prometida; 19) Ministério da Fé e Libertação; 20) Igreja Fé da Salvação do Espírito Santo (Ifesa).

3 Embora a Igreja dos Primogénitos não tenha profetisas, existem diaconisas, pastoras e conselheiras. Nesta igreja, os papéis das mulheres vão da limpeza e embelezamento e higiene da igreja, [continua] 
Viana, no quilómetro 12, encontra-se o Centro Terapêutico Tradicional Papá Nzuzi. Neste centro trabalha um casal de agentes tradicionais, o Papá Nzuzi e a sua mulher, parteira tradicional, a Mamã Glória. No centro, aos domingos é convidado um pastor de uma igreja neotradicional ou de uma neopentecostal para celebrar cultos aos doentes internados.

Para responder à complexidade das situações identificadas, optou-se, metodologicamente, por um estudo qualitativo, privilegiando as conversas informais, entrevistas semiestruturadas e abertas, e histórias de vida dos principais sujeitos, como profetas, profetisas e crentes. Estas ações foram levadas a cabo nos locais de culto. Observaram-se assim cultos, sessões de cura e outros ritos praticados nestas igrejas. A observação participante permitiu verificar no terreno o uso de saberes e práticas de cura nas igrejas neotradicionais de Luanda, contribuindo para uma melhor compreensão da (re)negociação de identidades no contexto urbano, com particular atenção às mulheres e aos papéis que desempenham nestas igrejas.

A ênfase na cura e no poder do Divino Espírito Santo são as duas características sui generis nestas igrejas. No entanto, a cura processa-se de modos diferentes e, apesar de pertencerem à mesma corrente do Espírito Santo, elas não constituem um todo homogéneo, cada igreja possui a sua particularidade. Em comum, há a utilização da ideia do Espírito Santo e a inclusão de elementos tradicionais, como farmacopeia local ou rituais que incluem outros elementos simbólicos ressignificados localmente, usados para conferirem força simbólica à organização da desordem vivencial individual, social, ou às relações com antepassados ou outros espíritos.

Este texto centra-se na emergência de três profetisas de igrejas neotradicionais: a Conceição, a Suzete e a Teresa. Estas pertencem ao Centro de Devoção Rainha Santa Isabel, Igreja Teosófica e Igreja Fé da Salvação, respetivamente. O pequeno relato etnográfico revela as inúmeras possibilidades de estudo existentes num contexto ainda em forte mutação social, económica, política e cultural.

\section{A (re)emergência das igrejas neotradicionais}

A relevância das igrejas em Angola tem sido alvo de estudo por parte de diversos autores, desde o período colonial. Cândido Ferreira da Costa foi um dos primeiros autores a fazer uma genealogia dos missionários cristãos do Espírito Santo em Angola (Costa 1970). Após a idependência, os movimentos religiosos começam a ser analisados com uma nova grelha analítica. Henderson (1990) analisa a distribuição das diferentes congregações e a sua influência étnica e territorial. Birmingham (1998) nota a relação de várias congregações com o comércio de escravos e posterior incursão para o interior pelo Estado colonial, 
enquanto Schubert (1999) e Péclard (1998) exploram a relação entre a igreja e os movimentos de libertação, notando o primeiro a relação da igreja com o processo de paz (Schubert 2000). Michael Comerford (2005) centra-se no papel da igreja no processo de paz após a guerra civil. Os movimentos messiânicos em Angola foram também tratados por vários autores (Freston 2001). Mais recentemente, Viegas tem publicado vários estudos sobre igrejas independentes africanas (agrupadas localmente, em função das suas afinidades, ora como igrejas neotradicionais, ora como igrejas do Espírito Santo, ora ainda como Movimentos de Reavivamento) e, juntamente com Blanes e Sarró, tem centrado o seu estudo nas igrejas kimbanguista e tocoísta. ${ }^{4} \mathrm{Em} 2014$, Blanes publicou uma biografia de Simão Gonçalves Toko, profeta da Igreja Tocoísta, enquanto Bahu produziu uma tese de doutoramento sobre curas religiosas no Lubango.

Considerando o que é uma igreja, parte-se da definição proposta por Viegas: "uma instituição aberta, formada por homens e mulheres hierarquicamente organizados, os quais mantêm relações normais com a sociedade, estando os seus discursos e práticas voltados para a resolução dos problemas espirituais e sociais. Por definição, igreja é uma 'estrutura aberta' onde na perspetiva de sociólogos não existem diferenças sociais e étnicas. Numa visão teológica é considerado o 'sacramento de salvação', por ser um espaço de perdão e reconciliação, um lugar de encontro e do diálogo” (Viegas 2007: 29).

O crescente número e importância local das igrejas neotradicionais, assim designadas por Dozon (1978: 115), fez destas um objeto preferencial, tendo o presente artigo privilegiado essa categoria, de que uma das características preponderantes é a atenção a questões de doença e cura, na sua dimensão fisiológica, mental ou espiritual. ${ }^{5}$

Estas novas congregações são amiúde consideradas pelas igrejas históricas angolanas (católica e protestantes) como seitas. Esta classificação evoca reinterpretações dos escritos sagrados feitas por estes movimentos mais recentes, mas, mais importante, cria um sentimento de alteridade de cariz negativo, de um outro novo, que remete para a ideia de logro, consequente de uma prática religiosa não ortodoxa segundo os movimentos religiosos históricos, bem como para a legislação sancionada pelo Estado.

4 Ver: Viegas (1999, 2005, 2007, 2008, 2010); Sarró, Blanes e Viegas (2008). As igrejas independentes surgiram noutras paragens do continente africano, como África do Sul, Gana e Zaire (Dozon 1978). Para uma bibliografia inicial sobre kimbanguismo, ver Chassard (1971).

5 Trata-se de instituições religiosas cuja prática doutrinal e rituais adaptam aspetos do cristianismo e elementos culturais da tradição africana. Estas instituições não constituem um todo monolítico; os seus rituais e as suas práticas variam de acordo com as suas doutrinas; no entanto, todas elas apresentam um eixo comum, ou seja, a crença no poder do Divino Espírito Santo, e por isso muitas são também designadas igrejas do Espírito Santo. Intitulam-se "Independentes" pelo facto de serem autónomas financeiramente em relação às igrejas históricas. A maior parte dos fundadores destas instituições e seus crentes provêm da Igreja Católica e de igrejas protestantes (pentecostais e evangélicas) - ver Viegas (1999). 
Dito isto, é imperioso recordar que as seitas cumpridoras dos ditames legais e outras instituições religiosas reconhecidas pela sociedade podem transformar-se em igrejas (Bahu 2014: 23), embora o inverso também possa ocorrer - há igrejas cuja existência deixa de ter uma sanção legal. A classificação como seita não é, portanto, fixa.

Durante grande parte do período colonial, o domínio da Igreja Católica era contrabalançado por algumas missões protestantes instaladas no território desde o século XIX. Na segunda metade do século XX, surgiram então movimentos sincréticos africanos que operaram à escala regional e nacional. A transição política pós-independência trouxe também modificações socioculturais profundas, com corolários nas biografias de milhões de angolanos. A posição destas igrejas pode, em certa medida, ser entendida pelo facto de serem um subproduto dos primeiros movimentos messiânicos africanos, nascidos como resposta à opressão colonial, como refere Lanternari (1963). Numa primeira fase, o regime marxista monopartidário menosprezava a importância da religião na construção do "Homem Novo", deixando as igrejas - cristãs e protestantes, mas também as neotradicionais como as kimbanguistas ou tocoístas num ambiente hostil. No final dos anos 80, o Decreto Executivo n. ${ }^{\circ} 7 / 87$ reconhece 12 igrejas: Igreja Evangélica do Sudoeste de Angola; Igreja Evangélica Congregacional de Angola; Igreja Metodista Unida; Igreja Católica; Igreja Evangélica de Angola; Igreja Evangélica Reformada de Angola; Igreja de Jesus Cristo sobre a Terra (kimbanguista); Igreja Evangélica Baptista em Angola; Assembleia de Deus Pentecostal; Igreja do Sétimo Dia; Convenção Baptista de Angola; União das Igrejas Evangélicas de Angola (Viegas 1999: 413).

O Decreto Executivo n. ${ }^{\circ}$ 46/91, do Ministério da Justiça e da Secretaria de Estado da Cultura, possibilitou aos cidadãos organizarem as suas igrejas numa tentativa de obterem reconhecimento legal do governo, e foi posteriormente substituído pela Lei n. ${ }^{\circ}$ 2/04 - Lei sobre o Exercício da Liberdade de Consciência, de Culto e de Religião -, bastante permissiva quanto à proliferação de movimentos religiosos. Até 2000 o Ministério da Justiça reconheceu 85 igrejas, existindo mais de 900 em processo de reconhecimento (Viegas 2008). ${ }^{6}$

Como refere o pastor Kiluanje, da Igreja dos Primogénitos Evangélica Universal, sobre a proliferação destes novos movimentos:

"No princípio da década 60 houve uma fuga maciça de cidadãos angolanos para outros países, sobretudo para o ex-Zaire [...] muitas dessas pessoas já tinham a sua crença religiosa e postos nestas partes onde eles..., portanto

6 Importa referir que compete ao Ministério da Justiça conceder o reconhecimento jurídico às igrejas, mas aquele por vezes solicita um parecer técnico ao Ministério da Cultura, mais particularmente ao Instituto Nacional para os Assuntos Religiosos (INAR), órgão vocacionado para o estudo, análise e divulgação de informação sobre os fenómenos religiosos (Viegas 2008). 
[...] trouxeram outras experiências religiosas [...]. Nós no princípio éramos 28 igrejas, depois surgiram muitas, mais ou menos em 93, 94, nós fizemos um levantamento, então nesta altura estávamos com cerca de 300, mas vi que surgiram outras denominações, penso que estas igrejas espirituais estão mais ou menos à volta de 400 aqui em Angola." [Kiluanje, entrevistado no local de culto, Luanda, 20 de dezembro de 2003]

As igrejas tradicionais apropriam-se de simbologias tradicionais da religião cristã, mas sobretudo das da tradição africana, as quais pareciam desaparecidas face à ordem política marxista e neoliberal que, num segundo período após a independência, privilegia o discurso do desenvolvimento, progresso e biomedicina. Isto foi particularmente vincado quando a política e a ciência foram apresentadas como garantia do desenvolvimento da nação, perante o sentimento de desencantamento com a ideologia marxista que se disseminou por Angola.

Esta é uma situação que ganhou maior ímpeto nos últimos anos. A Lei n. ${ }^{\circ}$ 2/04 estabelece os termos legais para o exercício religioso, reafirmando o artigo 10. ${ }^{\circ}$ da Constituição da República de Angola a laicidade do Estado, a separação entre este e as igrejas, ficando o primeiro munido do poder de reconhecimento e dever de proteção das várias confissões religiosas, desde que estas se conformem à Constituição e às leis da República. Mas, apesar de as igrejas católica e protestantes pretenderem manter a sua hegemonia e de serem históricas, os pastores neotradicionais referem que estas não respondiam às necessidades das populações. O dinamismo trazido por estas novas igrejas, centrado nos carismas do Espírito Santo, atrai populares e parece ser entendido como uma reação às igrejas históricas, sobretudo a católica e as protestantes. A este propósito, o pastor Kiluanje da Igreja dos Primogénitos Evangélica Universal afirma que:

"Essas igrejas não querem viver a realidade do Evangelho para poderem perpetuar a mentira, o engano, e para continuarem a terem aquilo que se pode dizer o domínio do povo, nós ensinamos ao povo a verdade [...] então à medida que essas pessoas vão tomando conhecimento da verdade, o povo vai vendo que eles afinal não têm importância nenhuma e eles têm medo de perder a hegemonia e vão ter que perder essa hegemonia e já perderam." [Entrevista no local de culto, Luanda, 20 de dezembro de 2003]

$\mathrm{Na}$ realidade, as igrejas neotradicionais, do Espírito Santo ou de Reavivamento vão surgindo cada vez mais no espaço urbano e periurbano e na sua maioria aguardam por um reconhecimento jurídico. Aliás, existem mais de mil igrejas por legalizar e, segundo o Jornal de Angola, existiam a 4 novembro 2013 quase 200 "processos de igrejas indeferidos". 


\section{Características das igrejas neotradicionais}

Os cultos religiosos têm uma importância central na sociedade tradicional angolana. A aceitação do monoteísmo, promovida durante o domínio colonial (Caley 201 l), é interpretada como "natural" devido às semelhanças com a cosmovisão banto (maioria da população angolana) a respeito da existência de um ser superior e omnipresente, que rege todos os aspetos da vida (Altuna 1993). ${ }^{7}$ Este ser supremo da cosmovisão banto atua como intermediário entre Deus e os agentes especializados dos grupos, através de seres "invisíveis" como, por exemplo, espíritos dos antepassados. Isto replica-se melhor no quadro ritualístico, explicativo e de autoridade carismática presente nas inúmeras denominações religiosas à espera de reconhecimento por parte do Ministério da Justiça.

Os líderes carismáticos destas igrejas recorrem ao Espírito Santo para libertar os crentes. Durante atos de possessão, de transe e de adivinhação, apregoam mensagens de salvação para uma sociedade angolana em que a maior parte da população vive abaixo do limiar da pobreza. Estas novas formas de religiosidade, muitas delas estrangeiras, exaltam um "Deus vivo" e trazem para o espaço sociocultural de Luanda outras "experiências" e outros "poderes religiosos", no domínio da espiritualidade, arrastando para o seu seio grupos de homens e mulheres que não se sentiam realizados na religião que perfilhavam (Viegas 2008).

Em simultâneo, estas igrejas promovem uma ação social, financiada pelas receitas, destinada a áreas como as da educação, saúde (cuidados biomédicos ou outros), solidariedade social (distribuição de alimentos, aconselhamento familiar) ou criação de emprego, entre outras. Estas práticas não só matizam as dificuldades sentidas pelas pessoas, como ocupam o vazio deixado pelos serviços estatais e privados ou pela ação insuficiente de outras igrejas, reforçando assim o potencial destas instituições numa Angola crescentemente neoliberal, mas ainda desenvolvimentista.

Para estas novas igrejas, a cura não se restringe à cura biomédica, sobrepondo-se o healing, ou seja, um conceito mais holístico de cura, que inclui elementos do contexto sociocultural a par do diagnóstico e terapêutica. Daí a centralidade destas igrejas e, no caso concreto, das profetisas enquanto promotoras deste processo de cura. No entanto, se a expectativa do crente não é "satisfeita", pode haver abandono da congregação.

À semelhança dos movimentos proféticos surgidos no meio do século XX, os movimentos neotradicionais após a independência também ressurgem para prometerem ao povo uma sociedade angolana melhor, onde reine a paz, a

7 Esse ser tem várias designações, de acordo com a variedade dos grupos etnolinguísticos, podendo haver no mesmo grupo mais do que uma designação, o que não altera este conceito de um ser superior e divino. Assim, no nosso grupo alvo com predominância kimbundu e kikongo, pode ouvir-se a palavra kalunga (kimbundu), o termo nzambi (kimbundu, kikongo), a palavra nfumu (kikongo), entre outras. 
harmonia, a solidariedade, baseada na caridade cristã (retomando o preceito de dividir tudo o que se tem, mesmo que só se tenha o amor pelo próximo) e com a tónica na tradição. ${ }^{8}$ Neste sentido, apropriam-se da ideia cristã de partilha e enriquecem-na de acordo com as suas próprias filosofias, resultando o "eu" e o "outro" estritamente ligados ao "Espírito Santo" e aos "espíritos dos antepassados", respetivamente. Nesta apropriação/transculturação dos valores religiosos, o comportamento dos neotradicionais não se afasta dos pilares cristãos, mas procura uma aproximação ao povo. Como nota Bahu, cada congregação quer marcar terreno, afirmando que tem uma interpretação mais próxima da verdade bíblica (Bahu 2014: 42).

A força destas igrejas está precisamente nos aspetos mais criticados pelas igrejas históricas, inclusivamente na reinterpretação dos textos sagrados, conjugada com elementos tradicionais. Estes crentes que vão às igrejas constituem as "comunidades carismáticas". Para Weber (na sua caracterização de tipo ideal), nestas comunidades não há hierarquias ou apropriação de poderes, salário ou outros benefícios. ${ }^{9}$ A relação estabelecida “... baseia-se numa forma emocional de relacionamento comunal (Vergemeinschaftung)", sustentada por "uma devoção pessoal completa ao líder, decorrente de entusiasmo, de desespero ou esperança". ${ }^{10}$ Para os fiéis, a legitimidade destas igrejas relaciona-se com a autoridade carismática manifestada através de revelações divinas, mais propriamente do Espírito Santo (veja-se adiante a secção sobre carisma e autoridade carismática). Contrariamente a outras áreas da sociedade angolana, estas comunidades carismáticas que as igrejas neotradicionais proporcionam não têm princípios de integração baseados na formação especializada (autoridade legal) ou de seleção por via de redes pessoais (autoridade tradicional), permitindo assim diminuir o sentimento de falta de autoestima e confiança ou de vulnerabilidade que caracteriza os crentes destas igrejas.

Os líderes carismáticos, incluindo as profetisas, objeto deste estudo, vão combinando diversos elementos da tradição judaico-cristã com elementos das religiões tradicionais. A cura é feita através do poder do Espírito Santo, com

8 Para mais informações sobre os movimentos proféticos, ver: Freston (2001); Sarró, Blanes e Viegas (2008); Sarró e Blanes (2009), Blanes (2014). O uso do adjetivo "tradicional" serve para caracterizar elementos e interpretações mais prístinos, sem que, no entanto, tenha conotações pejorativas, nem seja parte da díade "tradição/modernidade".

9 "There is no such thing as appointment or dismissal, no career, no promotion [... There is no hierarchy $[\ldots]$ there is no such thing as a $[\ldots]$ definite sphere of competence, and no appropriation of official powers on the basis of privilege [...] There is no such thing as a salary or a benefit" (Weber 1978: 243).

$10 \mathrm{Na}$ edição consultada: "An organized group subject to charismatic authority will be called charismatic community (Gemeinde). It is based on an emotional form of communal relationship (Vergemeinschaftung)" (Weber 1978: 243); "Those subjects so charismatic authority show [...] complete personal devotion [to the leader] arising out of enthusiasm, or of despair and hope" (Weber 1978: 242-243). 
recurso a vários rituais performativos que incluem atos de possessão, transe, glossolalia, e que têm como desiderato último a salvação presente da sociedade angolana. Isto porque profetas e profetisas neotradicionais são escolhidos pelo Espírito Santo como mensageiros prediletos, não aprendem a profissão, logo o conhecimento não se apresenta como uma continuidade, não obedece ao princípio de transmissibilidade.

Contudo, apesar de atuarem num contexto político e histórico diferente, experimentaram também uma situação de marginalização e um sentimento de subalternidade, pelo que se pode perceber das palavras do Pastor Kiluanje, da Igreja dos Primogénitos Evangélica Universal, na entrevista acima referida:

“[...] O ministro da Justiça, desde que entrou, reconheceu muito pouco dessas igrejas [...] o governo tem de respeitar o povo e este respeito passa precisamente pelo respeito de vários princípios indispensáveis, o certo é que eles respeitam a Igreja Católica e meia dúzia de igrejas [...] porque há igrejas que vieram, foram logo reconhecidas, elas são estrangeiras, a igreja Universal do Reino de Deus e outras tantas, a Maná... começam a explorar o povo e o Estado vê esta exploração e ninguém toca, mas, se notam algum defeito nas nossas, logo há muito barulho, mas quando há algum problema com a Católica não falam, quando há na Metodista não falam, há uma má política e é preciso que o Estado reveja, não é? [É preciso] aplicar a lei no sentido do reconhecimento dessas igrejas porque elas representam a nação angolana, [é] nestas igrejas [que está] inserida a verdadeira cultura da nação angolana."

Apesar de consubstanciarem os seus discursos e práticas em textos milenares, onde o Espírito Santo e a Bíblia constituem os pilares da cura, recorrendo a versículos como Romanos 12: 6-8 ou I Coríntios 12: 4-11, por exemplo, os neotradicionais pretendem apresentar-se como "modernos" na gestão da doença e da cura, identificando-se como cristãos.

Profetas ou profetisas são sujeitos que combinam os elementos das diferentes culturas, desempenhando amiúde papéis sociais diversificados. Por outro lado, a caracterização dos curandeiros como "incultos", "atrasados" e "diabólicos", em resultado da sua relação com a tradição, com os antepassados, não é linear. ${ }^{11}$ Entre os crentes das igrejas neotradicionais, há quem ainda recorra a curandeiros (Viegas 2008; Bahu 2014). Apesar da veiculada oposição entre igrejas neotradicionais e curandeiros, há curandeiros que criaram as suas

11 Segue-se neste artigo a seguinte definição de curandeiro: homem ou mulher dotado de poderes sobrenaturais recebidos pelos seus ancestrais que são normalmente usados para o bem, afastando influências maléficas de feiticeiros (Augé e Herzlich 1994: 17-18). 
próprias igrejas, e os que não o fizeram mas que ainda detêm credibilidade, legitimidade entre a população face aos resultados produzidos. ${ }^{12}$

O facto de o itinerário dos entrevistados demonstrar o recurso simultâneo a diversas práticas de cura alternativas significa que todas são interpretadas como necessárias, na medida em que o seu denominador comum é a resposta a questões centrais - $\mathrm{O}$ que aconteceu? Porque aconteceu? Porquê eu? Porquê agora? O que aconteceria se não tomasse providências? O que fazer e quem consultar para obter ajuda? - e a oferta de uma perspetiva de vida ou de prevenção da doença. Neste sentido, pode-se "sociografar" uma grelha composta por três grandes modelos para a cura:

- modelo inculcado pela tradição, com recurso à "feitiçaria", aos antepassados e ao curandeiro;

- modelo proposto pela Bíblia, baseado nas dicotomias bem $/ \mathrm{mal}$, Deus/satanás, bons espíritos/maus espíritos, e com recurso à igreja;

- modelo da medicina moderna, com as suas eventuais doenças orgânicas e psíquicas e o recurso aos hospitais.

A cura não só aparece como um alívio mais ou menos durável, mas também como retorno a um estado de bem-estar, onde o corpo e o espírito se encontram estreita e necessariamente associados.

Estas igrejas explicam o seu poder de cura pela atuação do "divino" através de rituais performáticos específicos. Porém, cada igreja apresenta um repertório próprio para a interpretação das causas das "doenças" (diagnósticos) e solução a considerar (terapêutica e cura). Enquanto uns recorrem à intervenção do Espírito Santo, outros invocam espíritos dos ancestrais e elementos da natureza e manipulam essas forças transcendentais através da unção com óleos, do recurso ao banho, por vezes misturado com sal ou aromatizado com perfumes e ervas ou flores, da proibição do uso de determinados alimentos, ou recorrendo a sessões de transe e possessão conseguidos pelo poder da oração individual e coletiva. Durante o processo de cura, o crente pode entrar em transe, ser possuído, ser capaz de glossolalia (falar em línguas estranhas), experiência que revela sempre a luta contra o mal. Mas no final a desordem estará reorganizada e a cura foi conseguida (Viegas 2008: 151; Bahu 2014). A cura, aqui tida como uma reorganização da sua experiência pessoal, um novo modo

12 As igrejas neotradicionais não constituem um todo monolítico, organizando-se cada uma de acordo com as suas afinidades e interesses. Um traço comum é a crença no Divino Espírito Santo e a partilha de um sentimento de se diferenciarem de outros atores, incluindo os curandeiros. Mas as "fronteiras" entre os dois tipos de agentes de cura são ténues: uns e outros oferecem cura para várias doenças, operam em transe na revelação e adivinhação, são intermediários de forças invisíveis; no entanto, enquanto os neotradicionais evocam o Espírito Santo, possibilitando curar como Cristo fez, nos terapeutas tradicionais estas forças são ancestrais (Viegas 2008). 
de ver o mundo e de se relacionar com outros (Rabelo 1998: 47), é o farol que leva pessoas a entrarem em contacto com estas igrejas, com estas profetisas.

Os crentes abençoados pelo Espírito Santo afirmam ter experimentado algo indiscritível - sentiram a cura -, uma vitória do bem, prova da força do Espírito Santo. No entanto, é importante notar que a resolução, ou o alívio do sofrimento, é compatível com a gestão de situações psicossociais, como casos de infidelidade, desentendimentos com a família ou vizinhos, falta de emprego, promoções sociais (Viegas 2008: 147).

$\mathrm{Na}$ paisagem urbana e espaço sociocultural de Luanda, as igrejas neotradicionais ergueram capelas e casas de oração e de cura. Nas terapias, renovaram tratamentos tradicionais, com rituais "esquecidos" como os "encostos", ou seja, os encantamentos; refizeram códigos de ética, de conduta religiosa e moral. Por outras palavras, desafiaram a sociedade tradicional, reinstalando a ideia da feitiçaria como a dualidade entre Deus e satanás, embora preservando um repertório mágico-ritual aliado à ideia axial do conhecimento místico do bem e do mal, pondo a tónica na presença dos espíritos malignos e do diabo à solta. Consequentemente, desenvolveram um sistema de "mercado mágico" atualmente aceite pelos mais distintos segmentos e classes da sociedade luandense, extravasando do local para a diáspora global (Sarró e Blanes 2009).

A emergência destes novos atores sucedeu numa conjuntura de extrema carência. A maioria da população vive uma situação de desencantamento relativamente às promessas da sociedade política pós-independência que se agudizou com a guerra civil e todo o lastro de violência, mas que persiste nos anos da década de 2000, tangível na dificuldade do Estado em fornecer educação, saúde e condições estruturais para a produção de emprego. A rápida proliferação destas igrejas parece ter sido uma resposta dinâmica aos problemas consequentes da guerra e migrações - falta de segurança, instabilidade económica geradora de altos índices de pobreza, acessibilidade reduzida à educação, saúde, água potável, saneamento básico e ausência de assistência social. As igrejas neotradicionais pretendem demonstrar que a religião deixa de ser um assunto privado para entrar na esfera do público, assumindo-se como livres gestoras, transformando a religião, através de reinterpretações bíblicas, numa nova fonte de imaginação simbólica, e procurando, assim, elidir as fronteiras simbólicas rígidas entre o campo religioso e o campo mágico, recolocando assim a igreja no itinerário terapêutico do enfermo e na (re)interpretação da cura.

É imperioso considerar o contexto de "violência estrutural" que molda e replica as estruturas de desigualdade onde as pessoas sobrevivem. ${ }^{13}$ É neste

13 Mecanismos de desigualdade e opressão estão inscritos nas estruturas socioeconómicas, consolidados ao longo de processos históricos transnacionais, incorporados no quotidiano daqueles que vivem em contextos de pobreza e privação, e consolidam modelos sociais e económicos de desigualdade ("sistema mundial") tangíveis em modos de violência quotidiana - desestruturação, desigualdade, discriminação, pobreza - e, no que concerne às infraestruturas sociais, no sistema de saúde pública (Farmer 2004: 307). 
contexto de pobreza que as igrejas neotradicionais prometem suprimir a doença e o mal, diminuindo a crise existencial, repondo a certeza nas ações e enfatizando sempre a eficácia da cura simbólica. O sentimento de pertença a comunidades religiosas, como referiu Durkheim (2002 [1912]), permite acalentar a esperança num futuro melhor que irá melhorar os quadros de exclusão social e vulnerabilidade, um futuro no qual o papel das profetisas se destaca.

Não obstante, é imperioso evitar uma atitude conformista ou passiva sobre os agentes e referir que, mesmo sob uma "violência estrutural", estes sujeitos, homens ou mulheres, têm capacidade de agência. ${ }^{14} \mathrm{Ou}$ seja, estas populações procuram soluções entre as várias práticas e saberes de cura existentes, numa utilização articulada segundo interpretações émicas dependentes de fatores culturais, económicos e políticos dos vários grupos sociais. Na realidade, muitos dos entrevistados evidenciaram a questão das oportunidades, informando que recorrem sobretudo à que está mais ao seu alcance. Neste "jogo" entre a doença, o infortúnio, a cura e a ordem de uma existência menos "dolorosa", o itinerário percorrido é variável.

Em suma, as novas dinâmicas religiosas desenhadas pela (re)emergência das igrejas neotradicionais propõem um novo ecumenismo (relações privilegiadas entre igrejas, pastores e comunidades); a recuperação da memória histórica e cultural (através da exaltação de figuras proféticas como Njinga Mbandi, Kimpa Vita, Kimbangu, entre outros): ${ }^{15}$ uma nova hermenêutica bíblica (adequada aos problemas comuns e quotidianos das pessoas, como história dos sofredores); e, ainda, uma certa recriação da feitiçaria (como causadora dos males - identificando e acusando, muitas vezes, velhos e crianças - que só pode ser vencida com o Espírito Santo). Paralelamente, as igrejas neotradicionais desenvolvem algumas estratégias peculiares de produção e gestão dos seus saberes e práticas de espiritualidade e de cura.

\section{SAÚDE, DOENÇA E CURA NA SOCIEDADE URBANA E PERIURBANA DE LUANDA}

A área da saúde apresenta-se como um campo particularmente permeável à atuação de outros sujeitos, face a um estado de depauperamento económico, insuficiência da rede sanitária, carência de profissionais de saúde com formação adequada e falta de um quadro deontológico dos terapeutas tradicionais. ${ }^{16}$

14 Para uma monografia sobre a temática, ver Farmer (1999).

15 A bibliografia sobre estes movimentos proféticos é vasta; sobre Kimpa Vita, ver Thornton (1998).

16 Para uma visão mais complexa sobre a relação entre medicina ocidental e tradicional, estabelecida por locais e por colonizadores, ver: Dias (1995), relativamente a medicamentos locais empregues em Angola nos séculos XVI a XVIII; Walker (2004a, 2004b, 2005), sobre o uso da medicina popular portuguesa nas colónias; Kananoja (2010, 2012), sobre crioulização em processos de cura em Angola no século XVIII. Sobre o uso estratégico da biomedicina por parte de angolanos, ver Varanda e Cleveland (2014). 
A observação empírica dos grupos afro-cristãos mostra que, na interpretação dos fenómenos sociais que impulsionam as suas vidas quotidianas, sobressaem três agentes do saber tradicional: o "adivinho", o "curandeiro" e o "feiticeiro". Cada um deles tem funções específicas, embora por vezes se apresentem ambíguos e atuem em articulação, enquanto detentores de saberes especializados, operando com eficácia na estabilidade emocional e nas práticas terapêuticas. ${ }^{17}$ Mas são os curandeiros - nsadisi - e, em particular, os pastores-terapeutas - bikudi - que são vistos como apaziguadores do sofrimento da população que vive em situações de crise económica, social e psicológica. ${ }^{18}$ No terreno, a estes atores ligados à gestão da doença e da cura juntam-se assim os agentes destas igrejas, entre os quais estão as profetisas.

\section{Corpo e saúde}

O corpo é um nexus entre a biologia e a cultura. É, portanto, uma entidade biológica saturada dos mais variados significados socioculturais, logo, peça central na construção identitária de qualquer sujeito. É pois através do corpo e respostas fisiológicas ou da incapacidade de realizar tarefas diárias que socioculturalmente se sancionam situações de bem ou mal-estar, classificações que não são retilíneas. ${ }^{19}$ Estes estados, aparentemente biológicos, legitimam hierarquias, diferenças ou exclusões, devendo estas classificações ser consideradas não como determinações sociais absolutas definidas biomedicamente, mas antes como processos em contínua negociação. A conceptualização de um corpo em estado enfermo é, assim, mais abrangente do que um problema físico ou mental, que o corpo-objeto resultado da rutura epistemológica cartesiana. ${ }^{20}$

17 Estas três figuras têm diferentes designações. Por exemplo, o "adivinho" em kimbundu e kikongo diz-se nganga, e o mesmo termo serve para designar "feiticeiro" nos dois grupos. No entanto, o termo "curandeiro" recebe diferentes designações: enquanto em kimbundu se diz mutombe e/ou musaxi, em kikongo empregam-se os termos uuki, untumbi e nganga. Gramaticalmente, nganga aparece como uma palavra homónima. Neste triângulo mágico-religioso - "adivinho", "curandeiro" e "feiticeiro" -, os dois primeiros agentes, considerados benéficos, detêm a função de diagnosticar e curar. Porém, muitas vezes, em determinados grupos sociais, estão representados pela mesma pessoa, o "adivinho/curandeiro", que ao ser por vezes malsucedido ou frustrado nas suas atividades se torna "feiticeiro". Neste caso, quase não se distinguem as duas figuras de "curandeiro" e "feiticeiro". Importa ressaltar que os três agentes por nós abordados não representam uma homogeneidade cultural, pois em cada grupo etnolinguístico se apresentam outras variedades e, por isso, ao delimitar estritamente as suas funções corre-se o risco de cometer imprecisões. Para exemplos da fluidez destas categorias e das práticas de fiéis na procura de resolução dos seus males no Lubango, ver Bahu (2014).

18 Em língua kikongo, nsadisi significa "curandeiro tradicional", isto é, pessoa dotada de poderes ancestrais para proteger e auxiliar indivíduos nos seus infortúnios, e bikudi é usado para referir alguém carismático, dotado de poderes de comunicação com a pessoa do Divino Espírito Santo.

19 Para leitura relativa ao corpo e vários sistemas de cura, em particular a biomedicina, ver Lock e Nguyen (2010).

20 Sobre o legado da conceção de Descartes, ver Eisenberg (1977); Scheper-Hughes e Lock (1987). 
No contexto em análise, estar de saúde relaciona-se não só com o bem-estar físico, demonstrado pela "capacidade produtiva", de realização de tarefas diárias, ou no agir de acordo com o que se espera de uma criança, jovem mulher, homem adulto ou idosos, mas vai, além disso, incluir múltiplas relações e interligações com esferas sociais - pessoal, familiar e comunitária/societal -, com ideias relacionadas com fé e pecado ou quebras de tabus locais. Esta conceção afasta-se do ideal definido pela Organização Mundial de Saúde em 1948, que afirma que saúde "é o estado do mais completo bem-estar físico, mental e social e não apenas a ausência de doença" (Last 1993), e tem corolários em termos de conceptualização de diagnósticos, terapêuticas e cura.

Considera-se assim a cura como conceito holístico, segundo o qual curar significa restaurar um modelo de saúde, entendido como normal e, por isso, não regrado pela doença. Ou seja, para o crente tem um impacto forte na "visão teológica" da sua existência. O simples ato da procura do médico não define a doença, terapêutica ou cura. A falta de saúde, traduzida em enfermidade ou infortúnio, aparece como a expressão da negatividade absoluta, torna-se paradigma do conflito (social, moral, psicológico), do caos e, enquanto metáfora, toma o significado da desordem por excelência.

Em termos de valor absoluto, a "saúde-instrumento" está ligada à economia tradicional e à expressão de uma "sociedade" rural e periurbana, onde a vida não é possível senão pelo trabalho diário. A saúde assim valorizada é fator indispensável ao trabalho e dá sentido à vida. No terreno, observou-se que ter problemas de saúde não é ter dores numa determinada parte do corpo, é ter uma aflição na totalidade existencial do sujeito. Como refere Boff, não é uma parte que está doente, mas é a vida que adoece em várias dimensões. A omnipresença da doença obriga o indivíduo a organizar, como achar mais adequado, o conjunto de discursos e de diferentes práticas e saberes médicos, com vista a obter um equilíbrio social, uma vida normal (Boff 1999: 143).

Como muitas vezes a causa da enfermidade é atribuída à chamada "feitiçaria", wanga ${ }^{21}$ a procura da saúde pode provocar ruturas que obrigam à realização de rituais (nas igrejas neotradicionais ou nos curandeiros) para fazer frente a "dramas sociais" que podem derivar em desintegrações e divisões familiares, muito embora os visados procurem a reconciliação e a reintegração social. ${ }^{22}$

21 O termo wanga é utilizado nas línguas angolanas umbundu e kimbundu.

22 Victor Turner esteve na génese da conceptualização do drama social (Turner 1996 [1957]). Como ilustram as perspetivas apontadas por alguns autores, a doença é muitas vezes considerada como castigo, conflito ou manifestação de tensões no tecido social e, por isso, por vezes, no grupo social em estudo, a procura de uma significação implica o envolvimento da família do doente, dos amigos e da vizinhança. O estudo de Janzen (1978), no antigo Zaire, é revelador da complexidade e importância do "grupo de gestão terapêutica”, enquanto a investigação de Habgood (1998) para a organização não governamental inglesa Oxfam mostra a centralidade destes grupos no contexto contemporâneo angolano. Para uma interpretação simbólico-estruturalista relativa ao contexto moçambicano, ver Fialho (2003). 
Os relatos dos fiéis confirmam que as representações da doença estão diretamente relacionadas com os usos sociais do corpo no seu estado normal. Mona nota que:

"Estar doente é não estar bem, porque estar doente é uma incomodação, não dá possibilidade de poder andar, ficas intimidado, não podes ir trabalhar, então para estares normal, para teres saúde, tens de procurar auxílio no doutor do hospital, nos enfermeiros, na nossa medicina tradicional. Ter saúde é fazer tudo." [Mona, crente da Comunidade do Espírito Santo, entrevistada por Fátima Viegas, 13 de setembro de 2003]

Com efeito, Weza também referiu que "sentir[-se] doente é não ter saúde, estar fraco, debilitado e a pessoa não poder fazer nada na vida, ficamos desesperados, sem saber programar a nossa vida"; sentimento reforçado por Muxito, ao afirmar que "a doença retrocede a vida, não se pode fazer nada, mesmo nada". ${ }^{2}$

Há um paralelismo com o contexto moçambicano, onde a doença também enfatiza a rutura da normalidade. A saúde é, portanto, um estado natural e esperado da pessoa, um estado harmónico que, por sua vez, para existir requer harmonia entre indivíduos, bem como na sua envolvente social e ecológica, incluindo os antepassados (Granjo 2009: 257).

\section{Percursos para a saúde}

A doença é por norma integrada num sistema multicausal complexo, onde se misturam elementos do mundo natural (micróbios, vírus), do mundo social (famílias e vizinhos) e do sobrenatural (maus espíritos, intervenção de forças mágicas e poder divino), quase servindo de base para os sistemas terapêuticos de Kleinman (1978) - popular, tradicional e profissional.

O pressuposto subjacente ao conceito de sistemas médicos relaciona-se com o conceito de pluralismo médico, numa sociedade onde existem e são usados diferentes setores ou tradições médicas. Assim, para este autor, o "sistema de cuidados" seria constituído pela interação de três setores (profissional, tradicional e popular), cada um com ideias e normas de conduta específicas e legitimando diferentes alternativas terapêuticas. Apesar de ser uma boa forma de conceptualizar a gestão terapêutica, este modelo replica ainda uma perspetiva funcionalista e tem uma conceção que sugere um sistema uno e integrado, algo que não se verifica no real.

Enquanto para alguns entrevistados a doença é antes de tudo uma manifestação de um poder sobrenatural e divino, para outros é muitas vezes também

23 Wesa é crente do Centro de Devoção Rainha Santa Isabel, entrevistada por Fátima Viegas em 27 de setembro de 2003; Muxito é crente do mesmo centro, entrevistado por Fátima Viegas em 3 de novembro de 2003. 
uma ação do homem, de acordo com a interpretação dos fenómenos da "feitiçaria" e da magia. Por não ser uma simples desordem biofísico-psicológica, faz parte do domínio mágico-religioso. O testemunho de Simba, um doente internado no Centro Terapêutico Tradicional Papá Nzuzi, ilustra a necessidade da intervenção dos dois mundos (visível e invisível) para a reposição do bem-estar saúde:

"Há quase três anos que tive problemas com minha barriga, sempre inchada, doía-me, parecia uma mulher grávida, não podia vestir umas calças com cinto, sentia-me mesmo mal. Fui ao hospital Maria Pia, estive durante cinco ou seis meses internado e não via cura. Um dia, um outro doente internado na enfermaria onde eu estava, ele também com um problema idêntico ao meu, os médicos resolveram tirar os líquidos que ele tinha no ventre, o senhor morreu! Ao ver isso comecei a ficar com medo e pedi ao médico para me dar alta, pois preferia morrer em casa, para não dar mais despesas à família, em alugar um carro para levar o meu corpo para casa. Saí do hospital e resolvi ir para Kinshasa, na República Democrática do Congo, à procura de outros meios."

Neste testemunho, a procura da medicina tradicional surge porque o doente não encontra os resultados desejados na medicina convencional moderna que procura em Luanda e na República Democrática do Congo:

"Lá estive também internado no hospital, mas fiz outros tratamentos tradicionais e não conseguia cura. Até que um dia, ao ouvir a rádio, escutei uma entrevista de um médico tradicional em Luanda, que explicava como ele tratava algumas doenças, então senti que ele havia de me curar. Regressei a Luanda e procurei este centro de cura, onde aqui estou a receber tratamentos há um mês, e já ponho normalmente calças, não sinto as dores que sentia, calço os sapatos, pois não podia fazer porque os pés estavam também inchados. O Papá Nzuzi me disse que era complicações com o aparelho digestivo, a verdade é que estou a recuperar a saúde. Simultaneamente, o Papá Nzuzi é também religioso e todos os domingos no centro é convidado um pastor das igrejas neotradicionais para a celebração de um culto, onde todos nós doentes recebemos a imposição das mãos e sentimos o peso da cura espiritual, os demónios são afastados." 24

A cura tradicional emerge para Simba como uma alternativa, um recurso num momento de desespero, ao vislumbrar a morte de outro individuo com 
uma nosologia semelhante à sua. Com este vislumbre da morte, o doente procura formas diversas de explicar a doença. Pode-se ainda afirmar que os sintomas vividos pelo doente iam para além do foro fisiológico, estando ligados à esfera do mágico e do transcendental. Assim, é sem surpresa que Simba, no seu testemunho, sublinha a eficácia da cura espiritual em oposição à ineficácia do tratamento hospitalar. Foi esta cura mágico-religiosa que permitiu ao entrevistado dar sentido ao fenómeno da doença.

Neste caso, a persistência de uma sintomatologia anormal, mesmo após práticas biomédicas, é reinterpretada e passível de ser tratada simbolicamente, isto é, através do recurso ao elemento "mágico" do poder curativo de um artefacto ou planta. ${ }^{25} \mathrm{O}$ que sobressai é a complexidade do itinerário terapêutico e as constantes negociações inerentes a cada tratamento, face à ausência de resultados satisfatórios para o grupo de gestão terapêutica (Janzen 1978). Este grupo, neste caso o doente e família, é central para a aceitação do diagnóstico e definição do processo terapêutico e da cura. Nele intervêm grupos de parentesco ou de vizinhança, tanto na escolha do sistema terapêutico quanto na formulação de hipóteses sobre as causas da doença e na procura de soluções através de modelos explicativos leigos (Young 1982). Este grupo torna-se sujeito do conhecimento sobre o mal-estar e avaliador de competências específicas que moldam as escolhas entre os diversos saberes médicos disponíveis.

O pluralismo médico verifica-se quando um sujeito, numa dada sociedade e numa determinada época, tem recurso a várias possibilidades terapêuticas, comportando cada uma delas os respetivos especialistas de cura. Pois "[...] cada doença dá origem a uma escolha entre as várias possibilidades" (Mbokolo 1994: 178). Mbokolo defende que a diferença entre as conceções da doença nas sociedades ocidentais e nas sociedades africanas reside no facto de que "as sociedades ocidentais estão mais preocupadas com a saúde do que com a doença, ao passo que sociedades 'tradicionais' africanas estão mais preocupadas com a doença, em fornecer interpretações e formas de combater" (Mbokolo 1994: 181).

Em conversas informais tidas no final de um culto religioso, os fiéis referiam a itinerância terapêutica e a ineficácia da biomedicina perante determinados males, em contraponto à eficácia e centralidade da medicina tradicional e das igrejas neotradicionais nestes percursos para o bem-estar:

"Se me sinto doente vou ao hospital, bebo os comprimidos que o médico receitou, mas tomo também o chá de plantas medicinais e na igreja recebo as bênçãos da profetisa e a unção com óleo benzido." [Crente da Igreja Fé da Salvação, em conversa informal com Fátima Viegas, 12 de março de 2003] 
Uma outra serviu-se de uma doença específica para dar o exemplo dessa itinerância:

"Aqui temos uma doença, chamam ongando ou olongado, em Malange chama-se mikila. Aquilo não é doença que passa ao outro, não é, só que no hospital não acusa nem tuberculose, nem paludismo. Então vamos a um curandeiro ou curandeira que sabe. Eles cortam e metem medicamento e passa, essa doença se chama makulo, se não se tratar, mata a pessoa. Os médicos nos hospitais não conhecem o modo de curar esta doença, só no tradicional." 26

Dois excertos de informantes internadas no Centro Tradicional Papá Nzuzi reforçam a ideia da consciência local do itinerário terapêutico, bem como das razões inerentes para tal.

Xana refere que:

"Meu marido procurou aqui este centro, vai ao hospital não consegue nada, fica pior. Eu sentia a doença tipo maluquice... desde que a família me trouxe na Igreja e centro tradicional... curei a minha vida." [Xana, entrevistada por Fátima Viegas em 13 de setembro de 2003]

Mena reforça a relevância do grupo de gestão terapêutica na definição do itinerário, bem como da negociação da própria "cura":

"Devo dizer que a família me trouxe aqui neste sítio mais rápido, a igreja onde eu ando também cura, mas demora tempo [...] o jeito que eu me encontrava, aqui cura mais rápido." [Mena, pastora da Igreja dos Primogénitos Evangélica Universal, internada no Centro Tradicional Papá Nzuzi, entrevistada por Fátima Viegas em 21 de setembro de 2003]

Os percursos terapêuticos são assim bastante mais complexos e menos ordenados do que se poderia considerar. Existe uma hierarquia de escolha de acordo com o diagnóstico efetuado pelo grupo de gestão terapêutica. O recurso simultâneo a vários tratamentos e a existência de visões discordantes - e até mesmo contraditórias - evidenciam que tanto a doença como a cura são experiências intersubjetivamente construídas. Por isso, o paciente, a sua família e aqueles que vivem próximo continuamente negoceiam significados (Janzen 1978; Rabelo 1998: 54). A existência e principalmente o uso destes significados pelas pessoas são também caóticos e indeterminados, chegando Last (1992) a sugerir o conceito de "não sistemas". 
A importância do grupo de gestão terapêutica e a maleabilidade dos modelos explicativos são aqui translucidamente reveladas. Ao "negociar-se" a avaliação da enfermidade/mal-estar, isto é, o diagnóstico, e na consequente definição do itinerário terapêutico, como nota Young, os modelos explicativos leigos podem modificar-se perante relações com modelos profissionais, mas também face às experiências vivenciadas pelo doente. Estes cruzamentos sugerem uma certa falibilidade nas medicinas, ou seja, nem os medicamentos químicos, nem os naturais receitados pelos terapeutas tradicionais, nem as intervenções dos neotradicionais são completamente eficazes. ${ }^{27}$ Esta ideia de fragilidade de cada um dos recursos médicos, devido às incertezas cada vez mais assentes na vida dos indivíduos, vai proporcionar a abertura a outros universos de significação da cura e da medicina.

Considerando os textos de Lévi-Strauss (1963), Singer (1990) e Moerman (1979, 2002) sobre o simbólico, a cura e a força do efeito placebo, há que considerar a "cura simbólica", isto é, a cura que não se restringe ao diagnóstico e terapêutica farmacológica para ser "eficaz", mas se alarga ao ritual e à manipulação de símbolos culturais poderosos. Na senda da "cura cultural" ou "cura simbólica", os pastores e profetisas das igrejas neotradicionais assumem uma importância capital, na medida em que o seu papel consiste em resolver os conflitos que causam a perturbação do doente, restaurar a coesão do grupo e reintegrar o doente na sociedade.

Os sistemas religiosos de cura oferecem uma explicação para a doença que a insere no contexto sociocultural mais amplo do sofredor (Comaroff 1985). Os rituais de cura (através da manipulação de símbolos num cenário carregado de emoção, entre cânticos, rezas, danças e transes) têm assim um papel transformador. Rabelo, ao estudar o ritual enquanto prática transformadora, refere que "no ritual da cura o doente é persuadido a redirecionar sua atenção a novos aspectos de sua experiência ou a perceber esta experiência segundo uma nova ótica" (Rabelo 1998: 49).

Alguns profissionais de saúde biomédica estão conscientes deste facto, como relata o médico Inocêncio de Sousa:

"Há pacientes que vão ao médico, mas muitas vezes antes de ir ao médico vai ao curandeiro, ou a um outro terapeuta tradicional, e concomitantemente vai ao pastor da igreja, porque ele procura a sua saúde; muitas vezes a procura de saúde não vê barreiras, o que ele quer é livrar-se do mal." [Médico do Hospital Maria Pia, entrevistado por Fátima Viegas, 20 de dezembro de 2003]

27 Considera-se aqui a terapêutica biomédica como um processo onde se integram a toma correta de medicamentos segundo prescrição médica, a origem dos medicamentos (se estes não vierem dos principais centros produtores a percentagem de princípio ativo presente pode variar), bem como o simbolismo dos medicamentos na cosmologia local. 
A complexidade do itinerário terapêutico indicia um questionamento implícito da qualidade e legitimidade das práticas médicas formalizadas e reconhecidas pelo Estado - no caso angolano, apesar da aproximação recente do governo aos terapeutas tradicionais, nomeadamente curandeiros, até à data da publicação deste texto, essas práticas centram-se exclusivamente na biomedicina. Este sancionamento de jure não tem corolário na práxis diária das pessoas, na qual a maioria da população recorre amiúde a outros saberes e práticas terapêuticas.

A análise do itinerário terapêutico exige uma interpretação interdisciplinar, inerente ao (re)emergir de novos atores como as profetisas das igrejas neotradicionais, em busca de uma matriz conceptual subjacente à lógica de incertezas e probabilidades do sistema curativo. Só assim se poderá compreender o fenómeno humano da procura de cura e da eficácia da cura religiosa. ${ }^{28}$ Curar é, portanto, um processo que implica uma interpretação causal da ligação do indivíduo ao contexto das relações sociais existentes, quer por diagnóstico científico, quer por adivinhação, ou ainda por outra "gestão terapêutica", como a cura religiosa.

Durante a pesquisa de campo, uma parte significativa dos fiéis apontava questões da enfermidade e de outro(s) sofrimento(s)/infortúnios como motivo da sua integração na comunidade religiosa. A cura não biomédica oferecida pelas igrejas neotradicionais torna-se um meio fundamental para atrair novos crentes. Esta cura abrange desde as perturbações mentais aos males somáticos e psicossomáticos, aos problemas de falta de dinheiro ou de desemprego, à falta de sorte ou perseguições nos serviços ou ainda às infelicidades conjugais. A tarefa das profetisas destas igrejas neotradicionais consiste em ajudar e curar as pessoas através da metamorfose sob a inspiração do Espírito Santo.

\section{O CARISMA E AS TRAJETÓRIAS DAS PROFETISAS}

Para os crentes, as profetisas possuem carisma. Comumente, o termo refere-se por norma à qualidade de alguém que apresenta e emana um "magnetismo pessoal" com a capacidade de conseguir a anuência de outrem. Mas é preciso definir melhor a sua aplicação para uma transformação religiosa que "compele" indivíduos a seguirem um líder. Assim, falar de carisma requer, necessariamente, evocar Sohm, que refere a importância dos carismas do Espírito Santo na igreja do primeiro século (Sohm 1958 [1896]). Max Weber apropria-se do conceito para o usar em campos além da religião, em outras estruturas de autoridade, como a economia e a política. ${ }^{29}$ Para este, carisma é "uma

28 Sobre a indeterminação das terapêuticas e o conhecimento que terapeutas e pacientes têm ou de que necessitam, ver Last (1992).

29 Parte integrante de um todo maior onde se destaca a teoria para ação elaborada contra a conceptualização utilitarista que ainda ia predominando. Para mais informação, ver Weber (1978: cap. I). 
qualidade particular de uma personalidade individual em virtude da qual ele é considerado extraordinário e tratado como dotado de poderes sobrenaturais, sobre-humanos, ou pelo menos com qualidades excecionais. Estas características não são acessíveis à pessoa comum, mas vistas como de origem divina ou exemplares" (Weber 1978: 241). ${ }^{30}$

A autoridade carismática resulta de uma mistura de elementos emocionais, valores e elementos racionais, no entanto não se afasta da ideia de uma graça de conhecimento divino, charisma veritatis (Sohm 1958 [1896]: 41). Weber clarifica a peculiar relação da autoridade carismática com a tradicional e a legal/burocrática: "O domínio carismático não conhece, portanto, os códigos jurídicos abstratos e os estatutos e nenhum modo formal de adjudicação. Sua lei 'objetiva' emana concretamente da experiência altamente pessoal da graça celestial e da força divina do herói. A dominação carismática significa uma rejeição de todos os laços com qualquer ordem externa, em favor da glorificação exclusiva da mentalidade genuína do profeta e herói” (Weber 1978: 174). Esta conceptualização de carisma ajuda a compreender a ressignificação da biografia das mulheres e por que razão elas podem assumir corajosa e diligentemente o que entendem ser as suas novas vocações e missões nas igrejas neotradicionais.

"O que é mais importante é como um indivíduo [carismático] é considerado pelos que estão sujeitos à autoridade carismática, pelos seus 'seguidores' ou 'discípulos'... O reconhecimento por parte daqueles que estão sujeitos à autoridade é o aspeto decisivo para a validade do carisma. O reconhecimento é livre e garantido pelo que é visto como prova, originalmente sempre um milagre, e consiste na devoção à revelação, culto do herói, ou uma absoluta confiança no líder" (Weber 1978: 242). ${ }^{31}$

Há, no entanto, que considerar ainda a força revolucionária do carisma, como nota Weber, pois em períodos tradicionais o carisma atua como força revolucionária (Weber 1978: 245) que transforma os indivíduos por dentro (Weber 1978: 11 16). Associar o conceito de carisma à participação e às

30 Na edição consultada: “The term 'charisma' will be applied to a certain quality of an individual personality by virtue of which he is considered extraordinary and treated as endowed with supernatural, superhuman, or at least exceptional powers or qualities. These are such as are not accessible to the ordinary person, but regarded as of divine origin or as exemplary, and on the basis of them the individual concerned is treated as 'leader" (Weber 1978: 241).

$31 \mathrm{Na}$ edição consultada: "What is alone important is how the [charismatic] individual is actually regarded by those subject to charismatic authority, by his 'followers' or 'disciples'... It is recognition on the part of those subject to authority which is decisive for the validity of charisma. The recognition is freely given and guaranteed by what is held to be proof, originally always a miracle, and consists on the devotion to the corresponding revelation, hero worship, or absolute trust in the leader" (Weber 1978: 242). 
trajetórias das mulheres nas igrejas neotradicionais significa, antes de mais, valorizar e respeitar as capacidades e potencialidades manifestadas por elas - em paralelo com os homens - nas respetivas comunidades religiosas.

\section{Trajetórias de vidas de mulheres profetisas}

Um atentar às características do carisma definidas por Max Weber, nomeadamente a sua irracionalidade face a regras, revela que o uso dos carismas por três mulheres é uma clara demonstração de capacidade de agência. Com o breve relato que se segue, de três histórias de vida de mulheres profetisas, centrado em vários indicadores descritivos - as origens geográfica, social e religiosa, os acontecimentos biográficos mais marcantes da vida e as características da igreja que lideram -, pretende-se mostrar como essas biografias ilustram o funcionamento destas igrejas e a origem dos seus carismas, ao mesmo tempo que reforçam a ideia de transformação num contexto de relações de género ainda conservador.

As características inerentes ao carisma, nomeadamente ao outorgar elementos de extraordinário, excecionalidade, sobrenaturalidade aos indivíduos, fazem com que este seja estranho à tradição. Isto possibilita que se vá contra as regras estabelecidas, ou seja, a atribuição de carisma às profetisas permitiu-lhes quebrar com as barreiras de género, construir novas identidades e aceder a lugares na organização da igreja que de outra forma lhes estavam barrados por questões de género. Weber apontou de forma clara a irracionalidade da autoridade carismática face às regras, nomeadamente à tradição: "A autoridade carismática repudia o passado, e é neste sentido uma força especificamente revolucionária. Ela não reconhece qualquer apropriação de posições de poder devido à posse de bens, seja por parte de um chefe ou de grupos socialmente privilegiados." 32

\section{Profetisa Conceição}

"Aos sete anos, os meus pais separaram-se [...] e comecei a viver com a minha avó, mãe do meu pai, que me deu uma educação cristã católica. Aos dez anos fui no internato, onde fiz a quarta classe. Depois, meu pai foi transferido para Waku Kungo e vivi lá com ele e a minha madrasta, onde concluí o ensino secundário. [...] Depois veio também novo conflito nos fins dos anos 74/75, entre UNITA e MPLA, antes, portanto, da independência. Íamos todos como refugiados do Waku Kungo para Malange. Quando atingi os meus 18 anos, comecei a trabalhar. Fui professora durante 7-8 anos. Depois comecei a ter problemas sérios de saúde. Então tive que parar, porque eram

32 Na edição consultada: "Charismatic authority repudiates the past, and is in this sense a specifically revolutionary force. It recognizes no appropriation of positions of power by virtue of the possession of property, either on the part of a chief or of socially privileged groups." (Weber 1978: 244). 
mesmo problemas também psíquicos. [...] Daí fizeram dois anos e oito meses de cama, [...] fiquei 24 horas em estado de coma. Mas, felizmente, o que Deus não quer não acontece e, portanto, depois de 24 horas só sei que recuperei os sentidos."

Não podendo continuar a ensinar, Conceição tentou exercer outra atividade, apesar de já ter tido visões sobre a sua missão. Durante a procura de outro emprego, os problemas de saúde persistiram.

"Fui me inscrever na Induve. [...] No dia seguinte, ao sair de casa para ir saber a resposta, só sei que caí desmaiada no portão. Levaram-me no hospital. O médico disse que não tinha nada. Morta não estava e doente também não."

Conceição continuava sem se sentir bem e foi procurar conforto e apoio junto de uma igreja católica, ao mesmo tempo que recorria a hospitais. Um dia, quando saía do hospital Maria Pia, viveu uma experiência inédita que mudou, finalmente, o rumo da sua vida.

"Vejo uma senhora a sair do hospital muito aflita com um menino de 5-6 anos. Disse que, depois de três meses internado, o médico disse que já não podia fazer nada. Eu perguntei a ela se tinha fé. Ela disse que tinha. Acompanhei-a até à casa dela e fui orando. [...] Uma voz que oiço aqui dentro: 'Agora chegou a sua vez, mostre!' E ponho a minha mão sobre o menino e fui orando mesmo sem saber o que havia de acontecer. [...] Pedi o azeite doce, pus nas minhas mãos e fui fazendo massagem ao miúdo e orando. Portanto, pus o miúdo de pé, despedi e disse: faça a medicação que o médico deu-lhes e amanhã vais com ele à missa. Fui para casa. Só sei que, no dia seguinte, levam-me o miúdo a andar."

Depois deste feito, Conceição passou a dedicar-se à oração e cura de doentes que vinham ter consigo até fundar a sua própria igreja, que por obediência à revelação divina resolveu designar Centro de Devoção Rainha Santa Isabel.

\section{Profetisa Suzete}

Também a profetisa Suzete revela a existência de um percurso de vida problemático, marcado por diversos episódios de doença, diagnósticos vários, diversas terapêuticas. As visões relatadas culminaram num despertar para ser profetisa. O ponto-chave aqui foi a sua última cura na casa do profeta Moisés II, da Igreja Teosófica.

"A minha mãe diz até hoje que sou, dos dez filhos que ela teve, a filha que mais trabalho lhe deu. Teve um parto complicado. Vim dentro de um saco, 
fiquei muito tempo dentro daquele saco e tiveram que cortar o saco para eu sair (meu pai era enfermeiro). Fui adoecendo e tratada pelo meu pai e minha mãe e fui vivendo. Aos nove anos [...] tinha sido abandonada pelo meu pai, eu e os meus irmãos. Aos dez anos, a minha vida se tornou um autêntico inferno [...] Passávamos fome, mesmo ainda em Malange. Alimentavam-nos de erva do campo fervida e simples que a minha mãe colhia.

[... Em Luanda, a minha mãe passou a levar-me ao médico com mais frequência - clínica geral e psiquiatrias. Mesmo assim não melhorava. Cresci a ser insultada por todos, porque eu tinha as crises também na escola ou em qualquer sítio. Caía no chão, atirava-me dos prédios e muros da escola, e janelas de casa, na sala de aulas gritava e desmaiava, porque via coisas estranhas. Vi um porco grande que estava a fumar atrás da casa, na minha janela.

Era atacada pelo Diabo, pois queria que eu trabalhasse com ele. Aí começou a intervenção de Deus contra o Diabo. As crises foram tantas que até os padres das paróquias de São Paulo, São Domingo e Sagrada Família reuniram e trocaram os santos todos desde São Pedro, Santo António, Nossa Senhora de Fátima, a Santa Maria Mãe de Deus e outros santos e benzeram a capela, benzeram a casa e os santos. [...] Nesta condição comecei a ajudar muitas pessoas em muitas áreas, sobretudo já falava de coisas boas ou más que iriam acontecer.

Em função do meu estado de saúde, o meu esposo [...] me abandonou com dois filhos.

Fui parar à Igreja Teosófica acompanhada de minha mãe. Na igreja fui recebida pelo profeta Moisés II [Rodrigo Van-Dúnem Domingos] e o seu colégio de trabalho. Aí comecei com as orações, fui melhorando e depois piorei. Até que o profeta Moisés II levou-me à sua casa e cuidou de mim, até que aos 2 de agosto de 1982 despertei."

\section{Profetisa Teresa}

No caso da profetisa Teresa, a biografia é marcada por momentos de doença e infortúnio, sendo o momento que definiu o seu poder terapêutico a previsão da conceção de uma criança. O seu carisma veio a confirmar-se com o salvamento dessa criança na sequência de um parto difícil.

"Nasci numa família católica e fui batizada aos doze anos. Durante toda a minha juventude sempre sonhava com um senhor alto vestido de branco. O meu pai faleceu quando eu era ainda miúda e vivi com a minha mãe.

Aos 25 anos tive uma revelação e fiquei muito doente. A minha mãe levou-me ao hospital, mas em vez de melhorar, piorava cada vez mais. Depois levou-me para vários quimbandas em busca de cura, mas também a doença continuava a piorar. [...] Um dia, ao ir a outro quimbanda, tive uma 
hemorragia e tiveram de me evacuar para o hospital. [...] Fiquei internada durante oito dias. [...] Os enfermeiros em serviço confundiram-me com outra jovem que tinha dado à luz um rapaz e fugiu depois do parto, abandonando o bebé no hospital. Eu neguei tudo, mas não aceitaram porque eu era parecida com aquela moça e o nome que estava no registo era igual ao meu. Oito dias depois fui ao tribunal para ser julgada. Então, a advogada me aconselhou e disse assim: 'Leva o bebé para casa, porque Deus talvez tem um propósito para contigo e a criança'." 33

Teresa não tinha alternativa senão acatar o conselho da advogada. Levou a criança consigo, dando-lhe o nome de Santo António. Porém, não dispondo de condições para criá-lo, decidiu entregar o bebé à sua irmã mais velha. A vida de Teresa mudou radicalmente de rumo depois de viver outro acontecimento marcante em Luanda, onde fora fazer o seu negócio como vendedora ambulante. Eis o registo das suas próprias palavras:

"Quando me preparava para descansar, passa por mim uma vizinha da minha sobrinha. O Espírito Santo revelou-me que ela estava grávida há dois anos e que andava em quimbandas para ter o bebé. Depois daquela revelação fui ter com a vizinha e lhe disse assim: 'Se não tirares aquele cinto que trazes amarrado na cintura, que o quimbanda onde tinhas ido procurar proteção te deu, não vais conseguir dar à luz o bebé.' A senhora ficou muito assustada e foi contar tudo ao marido e à sua família. Logo depois, começou a sentir dores de parto e deu à luz um rapaz. Mas, infelizmente, o parto correu mal porque a criança saiu com as pernas e acabou por falecer."

Como era de esperar, a família da parturiente responsabilizou Teresa pelo infortúnio e entregou-lhe o cadáver do bebé, na expetativa de obter uma solução. E o que sucedeu foi o seguinte:

"Fiquei com a criança até por volta da meia-noite. Naquele momento Deus enviou um profeta no meu corpo, o profeta Salomão. O Espírito Santo desceu sobre mim e comecei a soprar a criança pelos ouvidos e pelo ânus. Fiz isso várias vezes. A partir daí, a criança ressurgiu em meus braços. Este mesmo espírito deu o nome de São José à criança. A seguir entreguei a criança viva aos seus familiares. A partir dessa data comecei a fazer várias curas. Não parei mais."

33 Kimbanda, em kimbundu, designa o terapeuta tradicional que diagnostica as doenças e cura usando as plantas, embora possa igualmente comunicar com os espíritos dos antepassados e obter deles orientações terapêuticas. 
Quadro I

Quadro-síntese das trajetórias de vida das profetisas entrevistadas

\begin{tabular}{|c|c|c|c|c|c|}
\hline Nome & $\begin{array}{l}\text { Província } \\
\text { em que } \\
\text { nasceu }\end{array}$ & $\begin{array}{l}\text { Origem } \\
\text { social } \\
\text { e profissão }\end{array}$ & $\begin{array}{l}\text { Origem } \\
\text { religiosa }\end{array}$ & $\begin{array}{l}\text { Acontecimentos } \\
\text { marcantes } \\
\text { da vida }\end{array}$ & Carismas \\
\hline Conceição & Malange & $\begin{array}{l}\text { Família de } \\
\text { funcionários } \\
\text { públicos. } \\
\text { Foi } \\
\text { professora } \\
\text { primária. }\end{array}$ & $\begin{array}{l}\text { Católica. } \\
\text { Estudou } \\
\text { num } \\
\text { internato } \\
\text { da Missão. }\end{array}$ & $\begin{array}{l}\text { Separação dos pais; } \\
\text { migração; doenças } \\
\text { prolongadas, incluindo } \\
\text { transtornos mentais, } \\
\text { sonhos estranhos; } \\
\text { visões sobre a Rainha } \\
\text { Santa Isabel; curou } \\
\text { uma criança moribunda } \\
\text { que fora levada } \\
\text { do hospital sem } \\
\text { esperança; recuperou } \\
\text { a saúde quando assumiu } \\
\text { a "missão". }\end{array}$ & $\begin{array}{l}\text { Comunicar com } \\
\text { o Espírito Santo, falar } \\
\text { outras línguas, ter } \\
\text { visões, diagnosticar } \\
\text { doenças e males, curar, } \\
\text { pregar a Palavra } \\
\text { de Deus. }\end{array}$ \\
\hline Suzete & Malange & $\begin{array}{l}\text { Pai enfer- } \\
\text { meiro e mãe } \\
\text { doméstica. } \\
\text { Foi técnica } \\
\text { de laboratório } \\
\text { de análises } \\
\text { clínicas. }\end{array}$ & Católica & $\begin{array}{l}\text { Separação dos pais; } \\
\text { violações; fome; } \\
\text { migração; doenças } \\
\text { prolongadas, incluindo } \\
\text { transtornos mentais; } \\
\text { sonhos estranhos; visões } \\
\text { com anjos e profetas } \\
\text { bíblicos; restituiu } \\
\text { a vida a um peixe que } \\
\text { estava morto; obteve } \\
\text { cura na Igreja Teosófica } \\
\text { Espírita. }\end{array}$ & $\begin{array}{l}\text { Comunicar com } \\
\text { o Espírito Santo, visões, } \\
\text { diagnosticar doenças } \\
\text { e males, curar, pregar } \\
\text { a Palavra de Deus. }\end{array}$ \\
\hline Teresa & Benguela & $\begin{array}{l}\text { Família } \\
\text { camponesa. } \\
\text { Foi vendedora } \\
\text { ambulante } \\
\text { de fruta } \\
\text { e peixe seco. }\end{array}$ & Católica & $\begin{array}{l}\text { Morte do pai; fome; } \\
\text { migração; crises } \\
\text { de saúde, incluindo } \\
\text { transtornos mentais; } \\
\text { visões sobre o "profeta" } \\
\text { Salomão; restituiu } \\
\text { a vida a um bebé } \\
\text { que morreu durante } \\
\text { o trabalho de parto. }\end{array}$ & $\begin{array}{l}\text { Comunicar com o } \\
\text { Espírito Santo, visões, } \\
\text { diagnosticar doenças } \\
\text { e males, curar, pregar } \\
\text { a Palavra de Deus. }\end{array}$ \\
\hline
\end{tabular}

Foi na sequência destas experiências que Teresa iniciou a sua atividade de profetisa. Segundo ela, o número de pacientes e seguidores foi aumentando, até fundar a Igreja Fé da Salvação (Ifesa) em Viana. O menino referido na narrativa já completou 24 anos, emigrou para a Holanda e é atualmente o líder da Igreja Fé da Salvação naquele país. 
Os relatos destas três profetisas adequam-se à ideia formulada por Weber de que o carisma "pode efetuar uma reorientação subjetiva ou interna provocada por sofrimento, conflitos ou entusiasmo", pode levar à modificação radical das atitudes para com os problemas do mundo. ${ }^{34}$

A análise das histórias de vida e a leitura do quadro I levam-nos a concluir que existe uma semelhança estrutural nas trajetórias das três profetisas entrevistadas. A doença e o sofrimento pessoal marcaram os seus percursos anteriores à aceitação dos carismas recebidos e práticas inerentes a eles. Constata-se que a exclusão familiar e social remete para as visões comuns sobre as "doenças", entendidas como situações de "conflito". No entanto, o facto de terem sido agraciadas com carismas especiais criou novas oportunidades de emancipação e afirmação social e profissional.

\section{CARISMA E (RE)CONSTRUÇÃO DE IDENTIDADES E PAPÉIS DE GÉNERO}

A apresentação e a gestão de saberes e práticas de cura são feitas junto das comunidades nas igrejas neotradicionais. Esta cura religiosa, que tanto trata de doenças como de infortúnios, pode também ser conceptualizada como uma estratégia de poder destas igrejas face às igrejas históricas, um mecanismo de criação e delimitação de um espaço próprio. É neste contexto que vão emergindo redes de solidariedade, (re)construção de identidades e novas formas de emancipação social para as mulheres.

\section{Igrejas como sociedades-providência}

Perante as múltiplas formas de exclusão e discriminação sociais apontadas pelos entrevistados religiosos, muitas igrejas atuam como redes de interação complexas na construção de uma vida social com menos insegurança, numa sociedade em transformação. Estas instituições conseguem reintegrar indivíduos e criar um sentimento de comunidade religiosa, como referia Durkheim (2002 [1912]). Como pode verificar-se nas palavras da pastora Mafuta:

"Essas pessoas, à medida que vão para essas igrejas têm direito a comida, porque o povo é mobilizado, no sentido de contribuir com arroz [...] farinha, mandioca. Assistem e participam nas atividades da comunidade religiosa e são assistidos e há depois este convívio todo, uma assistência, fora do normal." [Entrevista por Fátima Viegas, 21 de dezembro de 2003]

34 Na edição consultada: "Charisma on the other hand, may effect a subjective or internal reorientation born out of suffering, conflicts or enthusiasm. It may then result in a radical alteration of the central attitudes and directions of action with a completely new orientation of all attitudes toward the different problems of the world" (Weber 1978: 245). 
As igrejas neotradicionais têm contribuído então para o apaziguamento das tensões sociais, ao mesmo tempo que constituem lugares de moralização, autênticas redes de solidariedade às populações, dando-lhes alimentos, curando feridas físicas e espirituais, ensinando, evangelizando e transformando mentalidades.

No período colonial, as igrejas atuavam nas áreas mais rurais e longínquas (Varanda 2007, 2014). Na entrevista já atrás citada, o pastor Kiluanje descreve como, similarmente, as igrejas mantêm um papel relevante de atores que representam ação junto do povo, desta feita em áreas urbanizadas, mas onde o Estado tem dificuldade em atuar:

"Durante o período das guerras civis, as igrejas africanas deram um grande contributo, resolvendo problemas de saúde e de ensino, assistindo as pessoas mais necessitadas. Lá onde não chega o Estado, está presente uma igreja ao lado do povo, minimizando os problemas quotidianos, construindo postos médicos, escolas e ajudando nas curas espirituais."

Homens e mulheres aderem a estas igrejas porque descobrem que este é "um novo modo de viver", baseado na ideia de uma solidariedade reencontrada, através de experiências individuais ou coletivas com a presença do Divino Espírito Santo:

“Tenho 49 anos de idade [...] estou nesta igreja há 21 anos. Eu me encontrava numa situação aflitiva, sem emprego, vagueava pelas ruas sem fazer nada, levava uma vida de boémio. Um dia... uma pessoa me fala desta igreja e vim aqui parar. Realmente, desde a minha integração, segui as orações, os encontros com os outros fiéis, para encontrar emprego, coisa que eu consegui... a minha família quase toda [mulher e filhos] estão nesta igreja." [Catembo, pastor da Comunidade do Espírito Santo, entrevistado no local de culto por Fátima Viegas, 18 de agosto de 2003]

Estas igrejas também alfabetizam crianças e adultos, socorrem em caso de doença e morte, criam empregos, associam-se às populações em momentos fulcrais nas biografias individuais ou familiares, como nos nascimentos e nos casamentos, atuando como providências. Estas práticas tecem laços de proximidade e solidariedade que suportam os encargos e as ajudas aos crentes. É por isso que se pode concluir que essas igrejas desempenham um papel de "sociedades-providência”, no sentido proposto por Santos (1995). Neste processo de fiação de redes de solidariedade, estas igrejas assumem uma postura emancipatória, na medida em que favorecem a "libertação" dos medos, das perseguições das forças malignas visíveis e invisíveis, integrando grupos de indivíduos no seio das famílias e das comunidades, levando-os à luta pelos seus direitos. 
Embora não substituam literalmente o Estado em termos de segurança social, estas novas congregações garantem segurança espiritual, solidariedade e apoio aos excluídos. Assim, na contemporaneidade, estas novas igrejas mantêm um papel-chave em zonas urbanas e periurbanas (Viegas 2008), em centros urbanos do interior, bem como em áreas rurais (Bahu 2014), onde a ação social do Estado é insuficiente.

\section{Construção de identidades próprias}

As igrejas neotradicionais apresentam características próprias nos rituais dos seus cultos, na sua composição e na sua mobilidade. Elas estão fortemente associadas aos idiomas sociais e culturais dos vários grupos etnolinguísticos que formam a nação angolana. Além do papel central destas igrejas junto da população para conforto espiritual ou pelas ações sociais, as igrejas são elementos importantes no esforço de reconstrução simbólica da nova nação angolana. Sobre isto, o pastor Kiluanje expressa o seguinte:

"Baseados nas potencialidades da nossa cultura e no princípio da valorização da nossa identidade, achamos oportuno sacudirmos o jugo do despotismo espiritual estrangeiro e reconquistar as antigas liberdades dos africanos, com as nossas igrejas nacionais reformadas e independentes, para a verdadeira reafirmação espiritual do homem africano." [Kiluanje, 20 de dezembro de 2003]

Na mesma linha de pensamento, o pastor Nsingui João remata que:

"Nós africanos temos uma graça única, o poder do Espírito Santo, coisa que não têm os europeus. Mamã Kimpa Vita, a nossa primeira profetisa, quando disse que tinha uma força interior e ajudou os nossos reis, os missionários europeus pensaram que ela estava maluca, porque os negros não podem saber estas coisas, falar coisas do céu. Foi por isso que surgiu Simão Kimbangu. Ninguém pode acabar com este dom. Em África, o Espírito Santo manifesta[-se] a favor dos que sofrem. É preciso que nós africanos te[nha]mos união para explorar esta graça, esta é a nossa identidade, que outras igrejas de fora não têm." [Nsingui João, pastor da Comunidade do Espírito Santo, entrevistado no local de culto por Fátima Viegas, março de 2003]

Neste contexto, as comunidades religiosas ganham um novo modelo de identidade, segundo o qual a personalidade de cada crente não está dependente da ligação com o seu ancestral, a sua linhagem ou o estatuto social da família, mas do privilégio de o seu "eu" entrar em contacto com o Espírito Santo. 
Esta nova intervenção de rituais religiosos parece ser uma força unificadora, uma forma não só de unir os adeptos, mas também de conferir legitimidade e respeitabilidade ao pastor, à profetisa ou à própria igreja. ${ }^{35}$

\section{Participação das mulheres nas igrejas neotradicionais}

O espaço e o papel ocupado pela mulher no seio destas igrejas são elementos revolucionários, pois aquela não tinha protagonismo no sistema tradicional nem nas igrejas históricas (católica e protestantes). Nas igrejas neotradicionais, é aberto um espaço público às mulheres, que atuam com novas funções e responsabilidades.

Nestas igrejas, as mulheres ocupam um lugar de destaque, transformando-se em visionárias e agentes importantes na preservação da família e da comunidade. As mulheres exercem o papel de verdadeiras educadoras das novas gerações e são responsáveis pela promoção de valores cristãos e culturais, como a solidariedade, pela continuação dos bons costumes e respeito pelos mais velhos, por exemplo, realizando visitas aos hospitais ou casas de cura e consolando as famílias dos crentes em situações de luto.

A questão da partilha de responsabilidades entre indivíduos de sexos e idades diferentes é visível na ordem das atividades quotidianas. Estas hierarquias estão presentes nas direções, no respeito pela experiência e sabedoria dos "mais velhos”, na inserção sociocultural dos jovens, nas estratégias para a reconciliação familiar, ou ainda na luta para minimizar a pobreza e a prostituição. Empenhando-se inteiramente no serviço, as mulheres ganham mais autoestima por estarem inseridas numa comunidade, onde o amor ao próximo e modos de participação social são enfatizados. A pastora Mafuta, da Igreja Teosófica Espírita, frisa que:

"Nós temos quatro tipos de obreiros que auxiliam esta instituição religiosa: as 'servas do tabernáculo' e 'servas espirituais', que participam nas curas divinas e assistem os trabalhos da vida material e espiritual; o 'corpo de intercessoras', que são o motor da igreja, nas campanhas de orações e visitas às famílias necessitadas; e os 'anciãos conselheiros', que cuidam da disciplina da igreja. Temos ainda grupos corais de jovens e crianças.” [Entrevista por Fátima Viegas, realizada no local de culto, Luanda, 21 de dezembro de 2003]

Os relatos das profetisas Conceição (fundadora e líder do Centro de Devoção Rainha Santa Isabel) e Suzete (líder da Igreja Teosófica Espírita) são claros a este respeito:

35 Para uma leitura detalhada sobre a eficácia de rituais, sagrados e seculares, ver Moore e Myerhoff (1997). 
"O preconceito existe. Eu enfrentei e continuo a enfrentar. Mas, felizmente, dentro da minha comunidade, eles sabem que eu sou a representante, sou mulher. Eles procuram sempre respeitar e aceitar aquilo que eu digo, seguindo os ensinamentos do Senhor. Mas também há quem vem, olha p'ra mim e não acredita. Porque eu não vou desobedecer à vontade de Deus e satisfazer os caprichos dos homens." [Conceição, entrevistada no Centro por Fátima Viegas em março de 2010]

"Fui escolhida pelo fundador para continuar a missão ou até morrer, dependendo da vontade de Deus. Sofri agressões e atentados... Só o facto de ser mulher nesta condição é um problema por parte dos conservadores e os que dizem ser melhores... Com muita fé e persistência, foi inaugurado o templo do Maculusso." [Suzete, entrevistada por Fátima Viegas em 2010]

Entre as funções específicas assumidas no interior das igrejas, podem referir-se as funções das "vates" (vaticinadoras ou mulheres que encarnam os espíritos). Cabe a estas mulheres pertencentes ao Centro de Devoção Rainha Santa Isabel e Igreja Teosófica diagnosticar os males dos pacientes e receber as orientações dos espíritos, para além de dirigirem as "sociedades" e "grupos" de intercessão, de cura e aconselhamento, bem como os grupos corais.

Importa realçar que, de um modo geral, a maioria dos crentes que acorrem às igrejas são mulheres com problemas de saúde que se referem a infertilidade ou gravidez prolongada, ${ }^{36}$ nosologias conceptualizadas localmente como problemas tradicionais, logo consideradas fora do alcance da medicina ocidental. Consequentemente, só a ação das profetisas com o poder do Espírito Santo podem curá-las.

"Na nossa igreja temos sociedades dos homens, de mulheres e dos jovens. Cada uma delas exerce as suas tarefas, uns dedicam-se ao ensino daqueles que não sabem ler e escrever; outros estão engajados nas tarefas de cura espiritual; outros fazem parte de grupos corais, todos trabalham para o desenvolvimento deste país." [Wenda, pastora da Comunidade do Espírito Santo, entrevistada no local de culto, 30 de setembro de 2003]

"Na minha igreja temos vários grupos corais de crianças, jovens e senhoras. Todos eles cantam e falam aquilo que lhes vai no coração, na alma. As mulheres têm um papel muito importante, são auxiliadoras no processo de cura, ajudam a esfregar o óleo benzido e a orar pelos doentes" [Kimbele, pastor da Igreja dos Primogénitos, entrevistado no local de culto, 12 de outubro de 2003]. 
A relevância das profetisas replica-se também na organização destas igrejas, onde elas ocupam lugares de chefia e fazem parte dos "conselhos". A participação destas mulheres contrasta com o que é regra noutras denominações religiosas, nas quais se restringe ao cuidar das estruturas físicas, limpeza e ornamentação, ou a atividades logísticas e protocolares, ou seja, onde essa participação se limita a uma replicação das tarefas consideradas tradicionalmente femininas, i.e. domésticas. Como refere a Mamã Luísa:

"Eu trabalho diretamente com o pastor, damos orações e bênçãos e trabalhos espirituais, eu tenho o dom do Espírito Santo. E há alguns serviços que nós é que temos de ver, somos a cabeça da igreja e ficamos a orientar, nós é que transmitimos [a]o pastor o que deve fazer." [Mamã Luísa, pastora anciã da Igreja dos Primogénitos, entrevistada por Fátima Viegas, no local de culto, 30 de setembro de 2003]

Este novo estatuto das profetisas tem contribuído para uma redefinição da conceptualização tradicional dos papéis de género, contrariando a discriminação sentida amiúde pelas mulheres nos mais diversos locais de trabalho. Esta renegociação de papéis pode assim contribuir para a sua emancipação.

\section{CONCLUSÃO}

Ao longo deste texto, verificou-se a importância da cura religiosa no contexto contemporâneo urbano da "grande Luanda". As dinâmicas sociais inovadoras engendradas a partir da complexidade sociocultural local supõem um cruzamento dos campos da saúde, por um lado, e da crença religiosa, por outro.

As igrejas neotradicionais reconstroem o espaço sociocultural de Luanda, erguendo templos e casas de oração e de cura, convertendo e arrastando multidões, refazendo códigos de ética e de conduta religiosa e moral, renovando certos rituais com a inclusão de elementos tradicionais, proporcionando em simultâneo um papel mais ativo às mulheres.

A religião ganha um peso desproporcional na identidade individual ou familiar. As redes sociais tecidas à volta da identidade religiosa permitem suavizar o peso da identidade individual de mulheres fragilizadas ou vulneráveis, e reencontrar um sentimento de solidariedade (espiritual ou não) inerente à experiência de um agregado de indivíduos sob um mesmo teto espiritual.

Nas igrejas neotradicionais, a mulher tornou-se um elemento revolucionário, ao assumir lugares de chefia e fazendo parte do conselho espiritual das igrejas. Como notou Weber (1978: 245), a autoridade carismática tem um cariz revolucionário e isso mesmo verifica-se no terreno. O papel de género feminino ganhou uma nova relevância no caso das profetisas, que se "movimentam" entre categorias e modelos abrangentes - pela (re)interpretação da 
Bíblia ou da "tradição" -, e pela forma como lidam com dilemas individuais (a incerteza, a desordem, o infortúnio, mal-estar ou doença).

Estas igrejas neotradicionais dirigidas por profetisas atuam onde o Estado está ausente ou é incapaz de solucionar as necessidades prementes das populações. A sua autoridade carismática e a legitimidade que têm entre os crentes revelam que vão cumprindo com as expectativas da comunidade de crentes. Apesar de serem ou poderem ser caracterizadas por outros atores como seitas, estas instituições são resultado de uma reapropriação do tradicional, ou da perceção da ação religiosa colonial, mas que, neste novo processo histórico da globalização e num terreno político crescentemente neoliberal, vão ganhado crescente relevância, pelo menos até ao questionar pelos crentes da legitimidade do carisma ou ao desaparecimento físico das profetisas.

\section{BIBLIOGRAFIA}

AltunA, Pe. Raul Ruiz de Asúa, 1993, Cultura Tradicional Banto. Luanda, Secretariado Arquidiocesano de Pastoral.

AUGÉ, Marc, e Claudine HERZLICH (orgs.), 1994, Le Sens du mal: anthropologie, histoire, sociologie de la maladie. Paris, Editions des Archives Contemporaines.

BAHU, Helder, 2014, Os Profetas e a Cura e pela Fé: Um Estudo Antropológico da Igreja de Jesus Cristo Salvador do Lubango. Lisboa, ISCTE-IUL, tese de doutoramento.

BIRMINGHAM, David, 1998, "Merchants and missionaries in Angola", Lusotopie, 1998: 345-355.

BlANES, Ruy Llera, 2014, A Prophetic Trajectory: Ideologies of Place, Time and Belonging in an Angolan Religious Movement. Nova Iorque, Berghahn Books.

BOFF, Leonardo 1999, Saber Cuidar: Ética do Humano, Compaixão pela Terra. Petrópolis, Vozes.

CALEY, Cornélio, 2011, "As religiões tradicionais africanas e universais em Angola em tempos de renascença", INAR: Actas do Workshop sobre o Fenómeno Religioso em Angola, Um Debate Recorrente" (Luanda, 14 e 15 de Junho), Luanda, INAR - Instituto Nacional para os Assuntos Religiosos, Ministério da Cultura, 19-28.

CHASSARD, Paul Eric, 1971, "Essai de bibliographie sur le Kimbanguisme", Archives de Sociologie des Religions, 31: 43-49.

COMAroff, Jean, 1985, Body of Power, Spirit of Resistance. Chicago, The University of Chicago Press.

COMERFORD, Michael G., 2005, O Rosto Pacífico de Angola: Biografia de Um Processo de Paz, (1991-2002). Windhoek, John Meinert Printing. 
COSTA, Cândido Ferreira da, 1970, Cem Anos dos Missionários do Espírito Santo em Angola, 1866-1966. Nova Lisboa, s/ed.

DIAS, José P. Sousa, 1995, "Índice de drogas medicinais angolanas em documentos dos séculos XVI a XVIII", Revista Portuguesa de Farmácia, 45 (4): 174-184.

DOZON, Jean-Pierre, 1978, "Os movimentos políticos-religiosos: sincretismos, messianismos, neotradicionalismos”, em Marc AUGÉ, A Construção do Mundo: Religião, Representação e Ideologia. Lisboa, Edições 70, 101-142.

DURKHEIM, Emile, 2002 [1912], As Formas Elementares da Vida Religiosa: O Sistema Totémico na Austrália. Oeiras, Celta Editora.

EISENBERG, L., 1977, "Disease and illness: distinctions between professional and popular ideas of sickness”, Culture, Medicine and Psychiatry, 1 (1): 9-23.

FARMER, Paul, 1999, Infections and Inequalities: The Modern Plagues. Berkeley, University of California Press.

FARMER, Paul, 2004, "An anthropology of structural violence", Current Anthropology, 45 (3): 305-325.

FIALHO, José, 2003, "A eficácia simbólica nos sistemas tradicionais de saúde”, Cadernos de Estudos Africanos, 4: 121-134.

FRESTON, Paul, 2001, Evangelicals and Politics in Asia, Africa and Latin America. Cambridge, Cambridge University Press.

GRANJO, Paulo, 2009, "Saúde, doença e cura em Moçambique”, em Elsa Lechner (org.), Migração, Saúde e Diversidade Cultural. Lisboa, Imprensa de Ciências Sociais, 249-274.

HABGOOD, Laura, 1998, Health and Livelihoods in Rural Angola: A Participatory Research Project. Oxford, Oxfam GB.

HENDERSON, Lawrence W., 1990, A Igreja em Angola: Um Rio com Várias Correntes. Lisboa, Editorial Além-Mar.

JANZEN, John M., 1978, The Quest for Therapy in Lower Zaire. Berkeley, University of California Press.

KANANOJA, Kalle, 2010, "Healers, idolaters, and good Christians: a case study of creolization and popular religion in mid-eighteenth century Angola", International Journal of African Historical Studies, 43 (3): 443-465.

KANANOJA, Kalle, 2012, "Central African identities and religiosity in colonial Minas Gerais”, Åbo, Åbo Akademi University, tese de doutoramento.

KLEINMAN, Arthur, 1978, "Concepts and a model for the comparison of medical systems as cultural systems", Social Science and Medicine, 12 (2B): 85-95.

LANTERNARI, Vittorio, 1963, The Religions of the Oppressed: A Study of Modern Messianic Cults. Nova Iorque, Knopf.

LAST, Murray, 1992, "The importance of knowing about not knowing: observation from Hausaland", em Steve Feierman e John M. Janzen (orgs.), Social Basis of Health and Healing in Africa. Berkeley, University of California Press, 393-406.

LAST, Murray, 1993, "Non-Western concepts of disease", em W.F. Bynum e Roy Porter (orgs.), Companion Encyclopedia of the History of Medicine. Londres e Nova Iorque, Routledge, vol. 1, 634-660.

LEVI-STRAUSS, Claude, 1963, "The effectiveness of symbols", em Claude Lévi-Strauss, Structural Anthropology, Nova Iorque, Basic Books, 186-205.

LOCK, Margaret, e Vinh-Kim NGUYEN, 2010, An Anthropology of Biomedicine. Oxford, Wiley-Blackwell. 
MBOKOLO, Elikia, 1994, "Histoire des maladies, histoire et maladie: l'Afrique", em Marc Augé e Claudine Herzlich (orgs.), Le sens du mal: Anthropologie, histoire, sociologie de la maladie. Paris, Editions des Archives Contemporaines (4. a edição), 155-186.

MOERMAN, Daniel A., 1979, "Anthropology of symbolic healing", Current Anthropology, 20 (1): 59-80.

MOERMAN, Daniel A., 2002, Meaning, Medicine and the "Placebo Effect". Cambridge, Cambridge University Press.

MOORE, Sally, e Barbara MYERHOFF (orgs.), 1997, Secular Ritual. Assen/Amesterdão, Van Gorcum.

PÉCLARD, Didier, 1998, "Religion and politics in Angola: the Church, the colonial State and the emergence of Angolan nationalism, 1940-1961", Journal of Religion in Africa, XVIII (2): 160-186.

RABELO, Miriam Cristina M., 1998, "Religião, ritual e cura", em Paulo César Alves e Maria Cecília de Sousa Minayo (orgs.), Saúde e Doença: Um Olhar Antropológico. Rio de Janeiro, Editora Fio Cruz, 47-56.

SANTOS, Boaventura de Sousa, 1995, "Sociedade-providência ou autoritarismo social?", Revista Crítica de Ciências Sociais, 42: i-vii.

SARRÓ, Ramon, e Ruy BLANES, 2009, "Prophetic diasporas: moving religion across the Lusophone Atlantic”, African Diaspora, 2 (1): 52-72.

SARRÓ, Ramon, Ruy BLANES, e Fátima VIEGAS, 2008, "La guerre dans la paix: ethnicité et angolanité dans l'Eglise kimbanguiste de Luanda”, Politique Africaine, 110: 84-101.

SCHEPER-HUGHES, Nancy, e Margaret M. LOCK, 1987, “The mindful body: A prolegomenon to future work in medical anthropology", Medical Anthropology Quarterly, 1 (1): 6-41.

SCHUBERT, Benedict, 1999, "Os protestantes na guerra angolana depois da independência”, Lusotopie, 1999: 405-413.

SCHUBERT, Benedict, 2000, A Guerra e as Igrejas: Angola, 1961-1991. Basel, P. Schlettwein Publishing.

SINGER, Philip, 1990, “Psychic surgery': close observation of a popular healing practice”, Medical Anthropology Quarterly, 4 (4): 443-451.

SOHM, Rudolf, 1958 [1896], Outlines of Church History. Boston, Beacon Press.

Thornton, John, 1998, The Kongolese Saint Anthony: Dona Beatriz Kimpa Vita and the Antonian Movement, 1684-1706. Cambridge, Cambridge University Press.

TURner, V.W., 1996 [1957], Schism and Continuity in an African Society: A Study of Ndembu Village Life. Oxford, Berg.

VARANDA, Jorge, 2007, “A bem da Nação': medical science in a diamond company in twentieth-century colonial Angola”. Londres, University College London, tese de doutoramento.

VARANDA, Jorge, 2014, "Cuidados biomédicos de saúde em Angola e na Diamang, das décadas de 1910 a 1970”, História, Ciências, Saúde: Manguinhos, 21 (2): 587-608.

VARANDA, Jorge, e Todd CLEVELAND, 2014, "(Un)healthy relationships: African labourers, profits and health services in Angola's colonial-era diamond mines, 1917-1975”, Journal of Medical History, 58 (1): 87-105.

VIEGAS, Fátima, 1999, Angola e as Religiões: Uma Visão Social. Luanda, edição de autor.

VIEGAS, Fátima, 2005, A Gestão da Doença no Espaço Sócio-Cultural e Urbano de Luanda: Os Curandeiros Tradicionais e os Neotradicionais. Coimbra, Universidade de Coimbra, dissertação de mestrado em Sociologia. 
VIEGAS, Fátima, 2007, Panorâmica das Religiões em Angola Independente: 1975-2007. Luanda, INAR - Ministério da Cultura.

VIEGAS, Fátima, 2008, "As igrejas neotradicionais africanas na cura e reintegração social (1992-2002): um estudo de caso em Luanda”, Revista Angolana de Sociologia, 1: 143-158.

VIEGAS, Fátima, 2010, "Saberes e práticas terapêuticas tradicionais à margem do sistema nacional de saúde: o caso dos curandeiros tradicionais em Angola”, Revista Angolana de Sociologia, 5-6: 117-130.

WALKER, Timothy, 2004a, "The role and practices of the curandeiro and saludador in early modern Portuguese society”, História, Ciências, Saúde: Manguinhos, 11 (supl. 1): 223-237.

WALKER, Timothy, 2004b, "Sorceres and folkhealers: Africans and the Inquisition in Portugal (1680-1800)”, Revista Lusófona de Ciência das Religiões, 5-6: 83-98.

WALKER, Timothy, 2005, Doctors, Folk Medicine and the Inquisition: The Repression of Magical Healing in Portugal During the Enlightenment. Leiden, Brill.

WEBER, Max, 1978, Economy and Society: An Outline of Interpretive Sociology. Berkeley, University of California Press, org. Guenther Roth e Claus Wittich.

YOUNG, Allen, 1982, "The anthropologies of illness and sickness", Annual Review of Anthropology, 11: 257-285. 